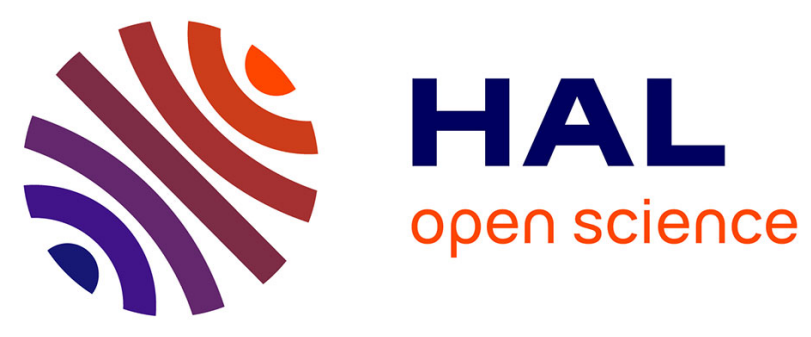

\title{
Oncological Outcomes of Laparoscopic Nephroureterectomy Versus Open Radical Nephroureterectomy for Upper Tract Urothelial Carcinoma: An European Association of Urology Guidelines Systematic Review
}

Benoit Peyronnet, Thomas Seisen, Jose-Luis Dominguez-Escrig, Harman Max Bruins, Cathy Yuhong Yuan, Thomas Lam, Steven Maclennan, James N'dow, Marko Babjuk, Eva Comperat, et al.

\section{To cite this version:}

Benoit Peyronnet, Thomas Seisen, Jose-Luis Dominguez-Escrig, Harman Max Bruins, Cathy Yuhong Yuan, et al.. Oncological Outcomes of Laparoscopic Nephroureterectomy Versus Open Radical Nephroureterectomy for Upper Tract Urothelial Carcinoma: An European Association of Urology Guidelines Systematic Review. European Urology Focus, 2019, 5, pp.205 - 223. 10.1016/j.euf.2017.10.003 . hal-03484986

\author{
HAL Id: hal-03484986 \\ https://hal.science/hal-03484986
}

Submitted on 20 Dec 2021

HAL is a multi-disciplinary open access archive for the deposit and dissemination of scientific research documents, whether they are published or not. The documents may come from teaching and research institutions in France or abroad, or from public or private research centers.
L'archive ouverte pluridisciplinaire HAL, est destinée au dépôt et à la diffusion de documents scientifiques de niveau recherche, publiés ou non, émanant des établissements d'enseignement et de recherche français ou étrangers, des laboratoires publics ou privés.

\section{(ㄷ)(1) $\$$}

Distributed under a Creative Commons Attribution - NonCommerciall 4.0 International 


\section{Oncological Outcomes of Laparoscopic}

\section{Nephroureterectomy Versus Open Radical}

\section{Nephroureterectomy for Upper Tract Urothelial Carcinoma:}

An European Association of Urology Guidelines

\section{Systematic Review}

Benoit Peyronnet a, ${ }^{a}$, Thomas Seisen ${ }^{b}$, Jose-Luis Dominguez-Escrig ${ }^{c}$, Harman Max Bruins $^{d}$, Cathy Yuhong Yuan ${ }^{e}$, Thomas Lam ${ }^{f, g}$, Steven Maclennan ${ }^{f}$, James N'dow ${ }^{g}$, Marko Babjuk ${ }^{\text {h, Eva Comperat }}$, Richard Zigeuner ', Richard J. Sylvester k, Maximilian Burger ', Hugh Mostafid m, Bas W.G. van Rhijn ${ }^{n}$, Paolo Gontero ${ }^{\circ}$, Joan Palou ${ }^{p}$, Sharokh F. Shariat ${ }^{9}$, Morgan Roupret ${ }^{b}$

a Department of Urology, CHU Rennes, Rennes, France

${ }^{b}$ Department of Urology, La Pitié-Salpétrière Hospital, Paris, France

c Department of Urology, Fundación Instituto Valenciano de Oncología, Valencia, Spain

d Department of Urology, Radboud University Nijmegen Medical Centre, Nijmegen, The Netherlands

e Division of Gastroenterology, Department of Medicine, McMaster University, Hamilton, ON, Canada

${ }^{f}$ Academic Urology Unit, University of Aberdeen, Aberdeen, UK

g Department of Urology, Aberdeen Royal Infirmary, Aberdeen, UK

h Department of Urology, Hospital Motol, Second Faculty of Medicine, Charles University, Praha, Czech Republic

i Department of Pathology, Tenon Hospital, Paris, France

j Department of Urology, Medical University of Graz, Graz, Austria

${ }^{k}$ European Association of Urology Guidelines Office, Brussels, Belgium

' Department of Urology, Caritas St. Josef Medical Centre, University of Regensburg, Regensburg, Germany

m Department of Urology, Royal Surrey County Hospital, Guildford, UK

${ }^{n}$ Department of Surgical Oncology (Urology), Netherlands Cancer Institute, Antoni van Leeuwenhoek Hospital, Amsterdam, The Netherlands 
- Department of Urology, University of Turin, Turin, Italy

p Department of Urology, Fundació Puigvert, Universidad Autónoma de Barcelona, Barcelona, Spain

q Department of Urology, Vienna General Hospital, Vienna, Austria

* Corresponding author. Department of Urology, CHU Rennes, Rennes 35000, France. Tel. +33665717254; Fax: +33299284321.

E-mail address: peyronnetbenoit@hotmail.fr (B. Peyronnet).

Keywords: Recurrence; Survival; Ureter; Ureteral neoplasms; Upper tract; Urothelial carcinoma; Laparoscopy

\section{Abstract}

Context: Most series have suggested better perioperative outcomes of laparoscopic radical nephroureterectomy (RNU) over open RNU. However, the oncological safety of laparoscopic RNU remains controversial.

Objective: To systematically review all relevant literature comparing oncological outcomes of open versus laparoscopic RNU.

Evidence acquisition: A systematic literature search using the Medline, Embase, and Cochrane databases and clinicaltrial.gov was performed in December 2014 and updated in August 2016. Randomised controlled trials (RCTs) and prospective or retrospective nonrandomised comparative studies comparing the oncological outcomes of any laparoscopic RNU with those of open RNU were included. The primary outcome was cancer-specific survival. The risk of bias $(\mathrm{RoB})$ was assessed using Cochrane RoB tools. A narrative synthesis of the evidence is presented.

Evidence synthesis: Overall, 42 studies were included, which accounted for 7554 patients: 4925 in the open groups and 2629 in the laparoscopic groups. Most included studies were retrospective comparative series. Only one RCT was found. RoB and confounding were high in most studies. No study compared the oncological outcomes of robotic RNU with those of open RNU. Bladder cuff excision in laparoscopic groups was performed via an open approach in most studies, with only three studies reporting laparoscopic removal of the bladder cuff. Port-site metastasis rates ranged from $0 \%$ to $2.8 \%$. No significant difference in oncological outcomes was 
reported in most series. However, three studies, including the only RCT, reported significantly poorer oncological outcomes in patients who underwent laparoscopic $\mathrm{RNU}$, especially in the subgroups of patients with locally advanced (pT3/pT4) or highgrade upper tract urothelial carcinoma (UTUC), as well as in instances when the bladder cuff was excised laparoscopically.

Conclusions: The current available evidence suggests that the oncological outcomes of laparoscopic RNU may be poorer than those of open RNU when bladder cuff is excised laparoscopically and in patients with locally advanced highrisk (pT3/pT4 and/or high-grade) UTUC.

Patient summary: We reviewed the literature comparing the outcomes of two different surgical procedures for the treatment of upper tract urothelial carcinoma. Open radical nephroureterectomy is a surgical procedure in which the kidney is removed through a large incision in the abdomen, while in laparoscopic radical nephroureterectomy, the kidney is removed through a number of small incisions. Our findings suggest that the outcomes of laparoscopic radical nephroureterectomy may be poorer than those of open radical nephroureterectomy, particularly when the bladder cuff is also required to be removed. Laparoscopic radical nephroureterectomy may also be less effective in patients with locally advanced (pT3/pT4) or high-grade upper tract urothelial carcinomas.

\section{Introduction}

Upper tract urothelial carcinomas (UTUCs) are relatively rare tumours with an incidence of 1.2 cases/100 000 inhabitants per year in Europe, which accounts for 5$10 \%$ of all urothelial carcinomas [1]. Radical nephroureterectomy (RNU) with bladder cuff excision is currently considered the standard of care for the curative management of high-risk UTUC [2]. First described in the early 1990s by Clayman et al [3], laparoscopic RNU has become widely popular during the past decade. Since then, various laparoscopic techniques of RNU have been described, such as the retroperitoneal route [4], hand-assisted laparoscopic RNU [5], or laparoendoscopic single-site RNU [6]. Several ways to manage the bladder cuff during laparoscopic RNU have also been proposed: through an open approach (either intravesical or extravesical excision), a laparoscopic approach (standard excision, endoGIA, 
Ligasure), or an endoscopic approach (transurethral resection with ureter stripping) [2]. More recently, a robot-assisted laparoscopic approach has been advocated by several authors in order to facilitate distal ureter management [7]. However, even though most series have suggested better perioperative outcomes using the laparoscopic route $[8,9]$, its oncological safety remains controversial, as cases of port-site metastases and tumour cell implantation have been reported [10], which may be due to a higher risk of tumour dissemination and seeding when manipulating UTUC under $\mathrm{CO}_{2}$ pneumoperitoneum [11]. Based on these considerations, there is an obvious need for evaluating the available evidence to define the optimal surgical approach for RNU. The primary objective of this systematic review (SR) was to assess the oncological outcomes of open RNU compared with those of laparoscopic RNU.

\section{Evidence acquisition}

\subsection{Search strategy}

A systematic literature search using the Medline, Embase, and Cochrane databases as well as clinicaltrial.gov was performed and updated by a research librarian in December 2014 and August 2016, respectively. The full search strategy was based on a free text protocol and is presented in the Supplementary material. Searches were limited to studies published from 1995 onwards and were conducted without language restrictions. Translation of any relevant non-English manuscripts was obtained from the European Association of Urology (EAU) Guidelines Office. Cited references from selected studies were also sought. The study protocol was registered in PROSPERO in April 2015 (CRD42015020737).

\subsection{Inclusion and exclusion criteria}

Studies were assessed using the PICOS approach in accordance with the Preferred Reporting Items for Systematic reviews and Meta-Analysis (PRISMA) guidelines [12]: patient, intervention, comparator, outcome, and study design. 


\subsubsection{Types of patients included}

The study population consisted of adult patients (>18 yr old) diagnosed with any grade and clinical stage (Tany, Nany, MO) UTUC treated with RNU. Populations excluded from this SR were individuals diagnosed with any clinical $M_{+}$, noncurative nephroureterectomy (NU), NU performed during excision of extra-upper tract tumour with local extension to the upper tract (eg, colon, duodenum, etc.), and NU with concomitant radical cystectomy.

\subsubsection{Types of interventions and comparators included}

Studies were considered eligible for this review if they compared the following:

1. Laparoscopic RNU (including robotic, laparoscopic, laparoscopic hand-assisted, and laparoendoscopic single-site RNU) with laparoscopic, endoscopic, or open bladder cuff excision

2. Open RNU with open or endoscopic bladder cuff excision

Laparoscopic RNU was categorised according to distal ureter management as pure laparoscopic RNU when bladder cuff was removed through laparoscopy, combined RNU when bladder cuff was removed through an open approach, laparoscopic RNU with endoscopic bladder cuff excision when bladder cuff was excised through an endoscopic approach, and unspecified laparoscopic RNU when no details regarding the approach for distal ureter management were provided or when several different approaches were used in the cohort.

\subsubsection{Types of outcome measures included}

Our primary outcome to measure oncological effectiveness was cancer-specific survival (CSS) at 1, 3, 5, and $10 \mathrm{yr}$. The secondary outcomes of interest were overall survival (OS), bladder recurrence-free survival (BRFS), recurrence-free survival (RFS), and port-site metastasis occurrence.

\subsubsection{Types of study designs included}

Randomised controlled trials (RCTs), as well as prospective or retrospective nonrandomised comparative studies, were included in this SR. Noncomparative studies, case reports, editorials, letters, review articles, and meeting abstracts were excluded during the review process. Studies also had to comply with the following inclusion criteria: a minimum follow-up of $1 \mathrm{yr}$ to assess the primary outcome, a 
minimum of 10 participants in each arm, and an appropriate comparison (ie, survival analysis) with at least one of the aforementioned oncological outcomes. Finally, if two or more studies reported outcomes of overlapping series (ie, by the same surgical team), the one with the largest sample size was selected.

\subsection{Study selection process}

After removal of duplicates, three authors (B.P., T.S., and J.L.D.E.) independently screened the titles and abstracts of 2363 records for eligibility. The full texts of 121 potentially eligible studies were retrieved and screened independently by two authors using a standardised form. Any disagreement was resolved by consulting the senior EAU Guidelines Associate (H.M.B.). According to the above-mentioned inclusion criteria, 41 studies were deemed relevant for this SR [5,9,13-51]. A PRISMA flowchart describing the study selection process is presented in Figure 1.

\subsection{Data extraction}

Data from all selected studies were independently extracted by the same three authors who performed the study selection (T.S., B.P., and J.L.D.E.), who subsequently cross checked to ensure accuracy. A standardised data extraction form was created and used to collect the following data: study design, number of patients, surgical approach (ie, laparoscopic, open, hand assisted, and robotic), surgical route (ie, transperitoneal or retroperitoneal), distal ureteral management (categorised as stripping, endoscopic, open extravesical, open intravesical, laparoscopic extravesical, or laparoscopic intravesical), pre- and postoperative clinicopathological characteristics, occurrence of port-site metastasis, and survival data, including estimated rates of CSS, OS, RFS, and BRFS at the time points provided by the authors, as well as their corresponding unadjusted and adjusted hazard ratios (HRs) with $95 \%$ confidence intervals (Cls).

\subsection{Assessment of risk of bias}

The risk of bias (RoB) for each study was independently evaluated by three reviewers (B.P., T.S., and J.L.D.E.) during data collection and according to the 
principles outlined in the "Cochrane Handbook for Systematic Review of Interventions" [52]. The reviewers assessed the reports in terms of allocation, sequence generation and concealment, blinding of participants, personnel and outcome assessors, completeness of outcome data, selective outcome reporting, and other sources of bias. In addition, the main confounders for the primary outcome (CSS) were identified a priori by the EAU UTUC Guidelines Panel. The reviewers assessed if each prognostic confounder had been considered by the authors and whether it was balanced across the groups or controlled for in multivariate analysis. The risk of confounding bias was considered to be high if the confounder was not reported or if it was reported but unbalanced among the treatment groups. Conversely, the risk of confounding bias was considered low if the confounder was reported and balanced among the treatment groups, or if it was unbalanced but adjusted for statistically. A RoB summary (Fig. 2) was generated using Cochrane RevMan software v.5.3 (Informatics and Knowledge Management Department, Cochrane, London, UK).

\subsection{Data analysis}

A narrative synthesis of included studies was carried out. Descriptive statistics were used to report baseline characteristics. Continuous variables were described using mean and standard deviation, or alternatively, median and interquartile range. Proportions were used to report categorical variables. Crude rates of the abovementioned survival outcomes were reported, as well as corresponding unadjusted and adjusted HRs. Statistical significance was defined as $p<0.05$. Studies were analysed separately according to the approach used for bladder cuff excision in the laparoscopic group (pure laparoscopic RNU, combined RNU, laparoscopic RNU with endoscopic bladder cuff excision, or unspecified laparoscopic RNU).

\section{Evidence synthesis}

\subsection{Characteristics of included studies}


Overall, the 42 included studies enrolled 7554 patients: 4925 in the open group and 2629 in the laparoscopic groups. The studies and patient characteristics are summarised in Table 1. The vast majority of included studies were retrospective comparative series. Only one prospective RCT was reported [9]. The retrospective series were multicentre studies $[22,23,34,41,44,49]$ and single-centre studies [5,13$21,24-33,35-40,42,43,45-48,50,51]$ in six and 34 cases, respectively. Most studies had small sample sizes (only six studies included over 100 patients in each treatment arm $[34,41,44,49-51])$.

\subsection{RoB and quality assessment of included studies}

The RoB and confounding assessment for all included studies are shown in Figure 2. Owing to their retrospective design, most included studies carried a high RoB across most fields of the Cochrane Collaboration tool. The issue of confounding was also poorly addressed by most studies as statistical adjustment was performed in only 11 out of 41 retrospective series, through multivariate analyses and match-paired comparison in nine and two cases, respectively, and all confounders were rarely taken into account. As an example, only two studies $[9,44]$ adjusted for the use of adjuvant chemotherapy.

\subsection{Results of comparisons of interventions}

\subsubsection{Surgical techniques}

Seven studies reported the oncological outcomes of hand-assisted laparoscopic versus open RNU [5,15,16,21,22,29,35], 33 studies compared laparoscopic with open RNU [9,13,14,17-20,23-28,30-34,36-45,47-51], and one study compared both laparoscopic and hand-assisted laparoscopic RNU with open RNU [46]. No studies compared the oncological outcomes of robotic RNU with those of open RNU. Laparoscopic RNU was performed through a transperitoneal route in 14 studies $[5,9,13,15,24-26,35-37,39,41,48,50]$, through a retroperitoneal route in 13 studies $[14,16,18-20,23,26,28,29,31,32,47,51]$, and through either a transperitoneal or a retroperitoneal route in four studies $[37,42,43,49]$. The other studies did not report the 
route that was used (ie, transperitoneal or retroperitoneal). Lymph node dissections were rarely performed and homogeneously distributed between open and laparoscopic groups.

\subsubsection{Distal ureter management}

Bladder cuff excision in laparoscopic groups was performed via an open approach in most studies (16/33, combined RNU), with only three studies reporting laparoscopic extravesical removal of the bladder cuff in all patients $[9,36,47]$ (pure laparoscopic $\mathrm{RNU}$ ) and four studies reporting laparoscopic removal of the bladder cuff in a minority of patients $[19,30,32,38]$. The distal ureter was managed endoscopically in four studies [13-15,30] (laparoscopic RNU with endoscopic bladder cuff excision). The approach for bladder cuff removal was not specified or heterogeneous in 15 studies (unspecified laparoscopic RNU). Only two studies reported no bladder cuff excision in some patients: it accounted for over a half of either open or laparoscopic cases in Capitanio et al's study [34], and only $1 \%$ and $3 \%$ of laparoscopic and open procedures, respectively, in the series by Kitamura et al [46].

\subsubsection{Lymph node dissection}

Only 22 studies reported whether a lymph node dissection was performed or not in each group, and none detailed the templates used. Of these 22 series, five reported a $100 \%$ rate of lymph node dissection in both groups $[18,25,26,30,35]$ and three studies reported a $0 \%$ rate of lymph node dissection in each group $[9,26,28]$. Three of the 14 remaining studies reported significantly lower rates of lymphadenectomy in the laparoscopic group $[34,41,44]$, while rates of lymphadenectomy were similar between the open and laparoscopic cases in the other series. Only one study reported a significant difference regarding the number of lymph nodes removed, favouring the open over the laparoscopic approach [19]. 


\subsubsection{Pathological findings}

No statistically significant differences in positive surgical margin (PSM) rates between the open and laparoscopic groups were reported in any studies. PSM rates ranged from $0 \%[15,24,29,32,33]$ to $17.4 \%$ [27] in laparoscopic cohorts and from $0 \%$ $[24,29,32,33,36]$ to $15 \%$ [14] in open cohorts. The reported $p N+$ rate was below $20 \%$ in all studies and comparable in open and laparoscopic groups. Advanced disease (pT3/pT4) accounted for over half of the cases in only two studies [35,49]. It is noteworthy that the rate of renal pelvis tumour (vs ureter) was significantly higher in the laparoscopic group in three studies $[21,34,39]$.

\subsubsection{Port-site metastasis and tumour seeding}

Comparisons of oncological outcomes are summarised in Table 2. Out of 18 studies that reported on port-site metastasis, four studies reported a total of six port-site metastases $[9,23,41,42]$. Port-site metastasis rates ranged from $0 \%$ to $2.8 \%$ [42]. No case of peritoneal or retroperitoneal carcinomatosis was reported.

\subsubsection{Combined versus open RNU}

Out of 16 studies, all retrospective, assessing combined RNU versus open RNU, only one study reported significantly different oncological outcomes between the two approaches [50]. In this single-centre series, Kim et al [50] compared 271 open RNU with 100 combined RNU and found significantly poorer OS (5-yr OS: $59.1 \%$ vs $75.2 \%, p=0.03$ ) and CSS (5-yr CSS: $66.1 \%$ vs $80.2 \%, p=0.01$ ) in the laparoscopic group. On stratifying patients according to tumour stages, significant differences in OS and CSS between the two surgical approaches were observed only in patients with locally advanced disease ( $\mathrm{pT} 3 / \mathrm{T} 4$ ), which was confirmed in multivariate analyses $(\mathrm{HR}=2.59, p=0.001$ and $\mathrm{HR}=2.50, p=0.005$ for overall death and cancer-specific death, respectively). Conversely, in a large multicentre French study, Ariane et al [41] reported a trend towards better CSS in patients who underwent 
combined RNU in univariate (5-yr CSS: $90.7 \%$ vs $78 \%, p=0.06$ ) and multivariate analyses (HR $=0.51,95 \% \mathrm{Cl}: 0.25-1.01, p=0.06)$.

\subsubsection{Pure laparoscopic versus open RNU}

The only RCT included in this SR was also one of the three studies comparing pure laparoscopic RNU with open RNU [9]. In this RCT, 80 patients were randomly assigned to laparoscopic RNU $(n=40)$ or open RNU $(n=40)$. CSS, BRFS, and metastasis-free survival (MFS) were found to be similar between the two groups when the entire cohort was considered ( $p=0.2, p=0.86$, and $p=0.12$, respectively). However, in the subgroups of pT3 UTUC and high-grade tumours, the authors reported better CSS and MFS in open, compared with laparoscopic, RNU ( $p=0.04$ and $p=0.004$, respectively, for $\mathrm{pT} 3 ; p=0.01$ and $p=0.01$, respectively, for highgrade disease) [9]. Greco et al [36] retrospectively compared 70 laparoscopic RNU with 70 open RNU, and found similar CSS but poorer RFS in the open group (5-yr RFS: $73 \%$ vs $75 \%, p=0.04$ ). Finally, in a small retrospective series without statistical adjustment, Fang et al [47] reported no significant differences between laparoscopic and open RNU regarding oncological outcomes.

\subsubsection{Unspecified/heterogeneous laparoscopic versus open RNU}

Most of the 19 studies comparing unspecified/heterogeneous laparoscopic RNU with open RNU reported comparable oncological outcomes between both groups, notably two series with a relatively large sample size and statistical adjustment through multivariate analysis $(\mathrm{HR}=0.88, p=0.6$ and $\mathrm{HR}=1.48, p=0.13$ for RFS, respectively, in the studies of Favaretto et al [38] and Walton et al [40]). However, in a multicentre series, Fairey et al [44] found a trend towards an independent association between laparoscopic RNU and poorer RFS in univariate and multivariate analysis ( $\mathrm{HR}=1.24, p=0.08)$. In the largest series published to date, Capitanio et al [34] reported better CSS and RFS in laparoscopic RNU in univariate analysis ( $p=0.008$ and $p<0.001$, respectively), but this difference was attributed to a selection bias favouring the laparoscopic group (ie, lower tumour grades and 
stages in the laparoscopic group). On multivariate analysis, a tendency towards an adverse impact of laparoscopy on survival was observed (HR = 1.54 for CSS, HR = 1.44 for RFS, $p=0.10$ in both cases). Finally, in a single-centre study including 108 patients in total, Kitamura et al [46] reported similar oncological outcomes between laparoscopic and open RNU, but significantly poorer BRFS in laparoscopic handassisted RNU than in open RNU (5-yr BRFS: $12.5 \%$ vs $71.1 \%, p=0.002$ ), which was confirmed in multivariate analysis ( $\mathrm{HR}=5.52, p=0.001)$. Interestingly, endoscopic ureteral management was performed in most laparoscopic hand-assisted RNU (66.7\%), while bladder cuff and distal ureter were removed through an open approach in laparoscopic RNU [46].

\subsubsection{Laparoscopic RNU with endoscopic bladder cuff excision versus open RNU}

None of the four studies comparing laparoscopic RNU with endoscopic bladder cuff excision to open RNU reported statistically significant differences between the two approaches in terms of CSS, OS, RFS, or BRFS [13-15,30]. However, it should be noted that all were small-sample, retrospective, single-centre series.

\subsubsection{Subgroups of locally "advanced diseases"}

Ten studies assessed the oncological efficacy of laparoscopic versus open NU in the subgroup of advanced diseases defined as pT3/pT4 and/or pN+ and/or high-grade tumours $[9,22,34,35,38,40,41,44,49,50]$. The results of these subgroup analyses are summarised in Table 3. Four studies reported significantly poorer oncological outcomes with laparoscopic RNU compared with open RNU in advanced diseases $[9,41,44,50]$. As mentioned above, in a prospective RCT including 80 patients, Simone et al [9] reported better OS and RFS in pT3 ( $p=0.04$ and $p=0.004$, respectively) and high-grade tumours ( $p=0.01$ and $p=0.01$, respectively) for open compared with laparoscopic RNU. In a single-centre retrospective series, Kim et al [50] observed poorer CSS and OS using the laparoscopic approach in pT3/pT4 UTUC in univariate ( $p=0.007$ and $p=0.005$, respectively) and multivariate analyses ( $p=0.005$ and $p=0.001$, respectively). Similarly, Ariane et al [41] reported 
significantly better CSS with the open approach for pT3/pT4 tumours $(p=0.05)$ and Fairey et al [44] reported better RFS for open RNU in pN+ tumours (HR =1.3, $p=$ 0.03). None of the 10 studies compared the local recurrence rates of open versus laparoscopic RNU in the subgroup of "high-risk" patients.

\subsection{Discussion}

Oncological efficacy of laparoscopy for the surgical management of urothelial carcinomas has raised concerns throughout the urological community for many years because of the expected higher risk of urine spillage [11]. While the perioperative benefits of laparoscopic RNU are supported by a large body of evidence [53], there is still controversy regarding its oncological safety. In a recent meta-analysis that assessed oncological outcomes of open versus laparoscopic RNU, published in 2012, Ni et al [10] included 21 studies and performed cumulative analyses. They found no significant differences between the two approaches in terms of OS, CSS, and RFS and concluded that laparoscopic RNU could offer comparable oncological efficacy to open RNU [10]. In the most recent meta-analysis, Zhang et al [54] found that laparoscopic NU could provide equivalent prognostic effects for UTUC, and could be associated with better extravesical RFS and CSS compared with open RNU. However, it should be emphasised that such a meta-analysis of retrospective data has inherent methodological flaws. Firstly, the authors pooled results from very heterogeneous series, analysing multiple surgical techniques (notably regarding distal ureter management) with different study designs (RCT or retrospective reports). Secondly, the selection bias favouring the laparoscopic group observed in most of the included studies [5,9,13-51] could not be statistically overcome by the meta-analytic approach. Conversely, in the present SR, given the low quality of available data in general, only a narrative analysis of included studies was performed. As opposed to the studies by Ni et al [10] and Zhang et al [54], in our SR some evidence emerged suggesting that laparoscopic RNU may not be as safe as open RNU, notably when the bladder cuff is excised laparoscopically $[9,46]$ and in patients with advanced (pT3/pT4) or high-grade disease [9,50].

In recent years, several studies have suggested a critical role for distal ureter management during RNU from an oncological standpoint $[55,56]$. Most studies 
included in the present SR reported a combined technique of laparoscopic RNU (ie, laparoscopic nephrectomy with open excision of the bladder cuff and distal ureter). Given that one out of three studies assessing pure laparoscopic (ie, with laparoscopic excision of the bladder cuff and distal ureter) versus open RNU—which was also the only randomised trial included in this review-reported poorer oncological outcomes in subgroups of patients treated with laparoscopic RNU [9], one could assume that laparoscopic bladder cuff removal may negatively impact the oncological outcomes of laparoscopic RNU. Two suppositions could be made to explain this finding. Firstly, as the laparoscopic dissection of the lower ureter may be technically challenging, the distal ureter could be incompletely excised with part of the intramural ureter and the ureteral orifice left behind, thus increasing the risk of local recurrence [57]. Although several studies have suggested the opposite [57], this risk of incomplete resection mainly concerns the laparoscopic extravesical technique [57], which was the technique used in the three series included in this review $[9,36,47]$. Another explanation for the presumed adverse impact of laparoscopic bladder cuff removal could be the increased risk of entering the collecting system due to the technical difficulty of such dissection, or to an opening in the bladder because of inadequate closure. As a result, laparoscopic bladder cuff removal could favour tumour spillage and tumour cell implantation [57].

Robotic RNU has spread significantly over the past few years and accounts for about a third of all RNUs performed in the USA according to recent data [58]. Given the ease of accessing the retrotrigonal region and the additional degrees of articulation afforded by EndoWrist instruments for closing the cystotomy [7], the potential benefit of the robotic approach over the laparoscopic approach for RNU would be to facilitate the laparoscopic excision of the distal ureter and bladder cuff. A key finding of the present $\mathrm{SR}$ is that, despite the recent surge in robotic RNU, no data were identified comparing the oncological outcomes of robotic RNU with those of open or laparoscopic RNU. Data comparing the oncological efficacy of robotic and open RNU are, therefore, urgently needed in order to address the concerns raised by the present report regarding the oncological safety of laparoscopic bladder cuff removal.

An important finding of the present SR is that in locally advanced high-risk UTUC (pT3/pT4 and/or high grade), laparoscopic RNU may result in inferior oncological outcomes compared with open RNU. Tumour biology and immunosuppression status 
have been shown to be the main risk factors of local recurrence [59]. Our results suggest that the potential for seeding may also be directly related to tumour aggressiveness. Another possible assumption to explain this finding is that quality of lymph node dissection may be better when performing open versus laparoscopic $\mathrm{RNU}$ and that this difference might, at least partly, explain the poorer oncological outcomes with laparoscopic RNU in locally advanced disease [60]. Consequently, careful patient selection based on tumour stage and grade might be paramount to ensure satisfactory oncological outcomes of laparoscopic RNU. Nonetheless, such selection could be challenging, as most of the subgroup analyses performed in the included studies were based on tumour grade and stage from the definitive pathological specimen [9,50], and it is well established that there is a poor correlation between clinical and pathological stage $[61,62]$ even though the correlation might be better for tumour grade [63]. Another issue related to this finding is that the abovementioned criteria that were used to define subgroups do not use the definition of risk groups according to current EAU guidelines [2], which makes it difficult to transpose these results to daily practice.

Several shortcomings of the present work should be emphasised. Firstly, very few retrospective series (nine out of 41 ) performed statistical adjustment for confounders, which made their findings difficult to interpret given the selection bias favouring the laparoscopic group in most of these series. Moreover, as highlighted by their large Cls and small sample size, most studies were underpowered to detect a difference in oncological efficacy between the two approaches. Another important shortcoming of this $\mathrm{SR}$ is that no series comparing oncological outcomes of open and robotic RNU were found, even though the latter approach, whose main theoretical advantage is the laparoscopic removal of the bladder cuff, has become increasingly popular during the past few years [58]. Furthermore, in none of the large multicentre studies, a description of the approach used for bladder cuff removal was provided. This negatively impacted our analysis as distal ureter management appeared to be a key factor of laparoscopic RNU oncological outcomes. This also prevented an assessment of the impact of bladder cuff management on oncological outcomes in each subgroup. None of the included series accounted for surgeon and hospital volume, which may be regarded as a shortcoming, as these two parameters have been shown to impact oncological outcomes of numerous surgical procedures [64]. 
Finally, the planned meta-analysis was not possible because of the heterogeneity of available data.

\section{Conclusions}

All but one of the included studies was retrospective series, and most reported similar oncological outcomes between laparoscopic and open RNU. In view of the current evidence base, and notably the only randomised trial available, the oncological equivalence of laparoscopic and open RNU is likely in most cases, but cannot be established when the bladder cuff is excised laparoscopically as well as in patients with locally advanced high-risk UTUC (pT3/pT4 and/or high grade). Distal ureter management (open vs laparoscopic) and patient selection based on tumour stage and grade could be the key points to ensure oncological efficacy of laparoscopic RNU, but these assumptions rely mostly on poor-quality data. Data comparing the oncological efficacy of robotic and open RNU are urgently needed, as there is a recent surge in robotic RNU, the main advantage in which lies in facilitating the laparoscopic excision of the distal ureter and bladder cuff.

Author contributions: Benoit Peyronnet had full access to all the data in the study and takes responsibility for the integrity of the data and the accuracy of the data analysis.

Study concept and design: Peyronnet, Roupret, Seisen, Bruins, Dominguez-Escrig, Babjuk. Acquisition of data: Peyronnet, Seisen, Bruins, Dominguez-Escrig, Yuan. Analysis and interpretation of data: Peyronnet, Seisen, Bruins, Dominguez-Escrig, Roupret.

Drafting of the manuscript: Peyronnet, Seisen, Roupret, Bruins, Dominguez-Escrig. Critical revision of the manuscript for important intellectual content: Babjuk, Comperat, Zigeuner, Sylvester, Burger, Mostafid, van Rhijn, Gontero, Palou, Shariat. Statistical analysis: None.

Obtaining funding: None.

Administrative, technical, or material support: N'Dow, MacLennan, Lam, Yuan. Supervision: N'Dow, MacLennan, Lam.

Other: None. 
Financial disclosures: Benoit Peyronnet certifies that all conflicts of interest, including specific financial interests and relationships and affiliations relevant to the subject matter or materials discussed in the manuscript (eg, employment/affiliation, grants or funding, consultancies, honoraria, stock ownership or options, expert testimony, royalties, or patents filed, received, or pending), are the following: B. Peyronnet: company consultant for Astellas and Boston scientific; trial participation in Ipsen and Allergan. T. Lam: company consultant for Pfizer, GSK, Astellas, and Ipsen; receipt of company speaker honorarium from Pfizer, GSK, Astellas, and Ipsen. M. Babjuk: company consultant for Astellas and Ipsen; receipt of company speaker honorarium from Ferring and GSK; trial participation in Sotio. R. Zigeuner: receipt of company speaker honorarium from Pfizer, Bayer Healthcare, Roche, Novartis, Ipsen, Glaxo Smithkline, and Amgen; receipt of fellowship and travel grants from Bayer Healthcare, Pfizer, Amgen, Novartis, Glaxo Smithkline, Astellas, and Takeda; receipt of grants/research supports from Bayer Healthcare; company consultant for Pfizer. M. Burger: company consultant for Astellas, BMS, Ipsen Pharma, Janssen, Pfizer, Springer, Thieme, Cepheid, and Merk Sharp Dome; receipt of company speaker honorarium from Astellas, BMS, Ipsen Pharma, Janseen, Pfizer, Springer, Thieme, and Bayer; trial participation in Photocure SA and Ipsen.

H. Mostafid: company consultant for Kyowa Hakko UK; receipt of company speaker honorarium from Prostrakan; spouse/partner of Combat Medical; trial participation in MSD. B. van Rhijn: company consultant for Astellas 2015. P. Gontero: company consultant for Andromedical; trial participation in Astellas. J. Palou: company consultant for Olympus, Allergan, IBSA, and Olympus; receipt of company speaker honorarium from Sanofi-Pasteur and General Electric; trial participation in Combat Medical and Presurgy. S. Shariat: company consultant for Astellas, Olympus, Wolff, Ipsen, Cepheid, and Janseen; receipt of company speaker honorarium from Lilly, Astellas, Ipsen, Olympus, Wolff, and Janssen; trial participation in Alere Inc. trials on NMP22, Roche, MSD, and BMS; participation in a company-sponsored speaker's bureau in BMS, MSD, Roche, Ipsen, and Olympus; other interests in BMS, Janssen, Wolff, Olympus, Astellas, and MSD; receipt of honoraria or consultation fees from Astellas, Olympus, Wolff, Ipsen, Janssen, and Roche; receipt of grants/research supports from Astellas and Sanofi; patents: 2001 Shariat S. and Slawin K.: Methods to determine prognosis after therapy for prostate cancer. U.S. Patent Application Serial Number: Docket\#60/266,976. Filed May 31, 2001; 2001 Shariat S., Lerner S. and Slawin K.: Methods to determine prognosis after therapy for bladder cancer. U.S. Patent Application Serial Number: Docket\#675.003US1. Filed June 1, 2001; 2002 Shariat S., Slawin K., Kattan M., and Scardino P.: Pre- and posttreatment nomograms for predicting recurrence in patients with clinically localized prostate cancer that includes the blood markers interlukin- 6 soluble receptor and transforming growth; 2003 Slawin K., Kattan M., Shariat S., Stephenson A., and Scardino P.: Nomogram for predicting outcome of salvage radiotherapy for suspected local recurrence of prostate cancer after radical prostatectomy. U.S. patent application serial number: Docket\#.Fi 2005 Shariat S. M. Rouprêt: company consultant for Lilly, GSK, Ipsen, Astellas, Takeda, and Sanofi Pasteur; trial participation in GSK, Pfizer, and Roche; receipt of company speaker honorarium from Roche and Zambon. J.-L. Dominguez-Escrig, T. Seisen, H.M. Bruins, J. N'Dow, E. Comperat, R. Sylvester, S. MacLennan, C.Y. Yuan have nothing to declare.

Funding/Support and role of the sponsor: None. 


\section{References}

[1] Siegel RL, Miller KD, Jemal A. Cancer statistics, 2016. CA Cancer J Clin 2016;66:7-30.

[2] Rouprêt M, Babjuk M, Compérat E, et al. European Association of Urology Guidelines on upper urinary tract urothelial cell carcinoma: 2015 update. Eur Urol 2015;68:868-79.

[3] Clayman RV, Kavoussi LR, Figenshau RS, Chandhoke PS, Albala DM. Laparoscopic nephroureterectomy: initial clinical case report. J Laparoendosc Surg 1991;1:343-9.

[4] Tan BJ, Ost MC, Lee BR. Laparoscopic nephroureterectomy with bladder-cuff resection: techniques and outcomes. J Endourol 2005;19:664-76.

[5] Raman JD, Palese MA, Ng CK, et al. Hand-assisted laparoscopic nephroureterectomy for upper urinary tract transitional cell carcinoma. JSLS 2006;10:432-8.

[6] Rais-Bahrami S, Kavoussi LR, Richstone L. Laparoendoscopic single site (LESS) nephroureterectomy: an overview of techniques \& outcomes. Arch Esp Urol 2012;65:311-7.

[7] Zargar H, Krishnan J, Autorino R, et al. Robotic nephroureterectomy: a simplified approach requiring no patient repositioning or robot redocking. Eur Urol 2014;66:769-77.

[8] Hanna N, Sun M, Trinh QD, et al. Propensity-score-matched comparison of perioperative outcomes between open and laparoscopic nephroureterectomy: a national series. Eur Urol 2012;61:715-21.

[9] Simone G, Papalia R, Guaglianone S, et al. Laparoscopic versus open nephroureterectomy: perioperative and oncologic outcomes from a randomised prospective study. Eur Urol 2009;56:520-6.

[10] Ni S, Tao W, Chen Q, et al. Laparoscopic versus open nephroureterectomy for the treatment of upper urinary tract urothelial carcinoma: a systematic review and cumulative analysis of comparative studies. Eur Urol 2012;61:1142-53. 
[11] Rouprêt M, Smyth G, Irani J, et al. Oncological risk of laparoscopic surgery in urothelial carcinomas. World J Urol 2009;27:81-8.

[12] Moher D, Liberati A, Tetzlaff J, Altman DG, PRISMA Group. Preferred Reporting Items for Systematic Reviews and Meta-analyses: the PRISMA statement. BMJ 2009;339:b2535.

[13] Shalhav AL, Dunn MD, Portis AJ, Elbahnasy AM, McDougall EM, Clayman RV. Laparoscopic nephroureterectomy for upper tract transitional cell cancer: the Washington University experience. J Urol 2000;163:1100-4.

[14] Gill IS, Sung GT, Hobart MG, et al. Laparoscopic radical nephroureterectomy for upper tract transitional cell carcinoma: the Cleveland Clinic experience. J Urol 2000;164:1513-22.

[15] Stifelman MD, Hyman MJ, Shichman S, Sosa RE. Hand-assisted laparoscopic nephroureterectomy versus open nephroureterectomy for the treatment of transitional-cell carcinoma of the upper urinary tract. J Endourol 2001;15:391-5.

[16] Kawauchi A, Fujito A, Ukimura O, Yoneda K, Mizutani Y, Miki T. Hand assisted retroperitoneoscopic nephroureterectomy: comparison with the open procedure. $J$ Urol 2003;169:890-4.

[17] Kim DW, Ryu DS, Oh TH. Initial experience of retroperitoneal nephroureterectomy for upper urinary tract transitional cell carcinoma. Korean J Urol 2005;46:382-7.

[18] Tsujihata M, Nonomura N, Tsujimura A, Yoshimura K, Miyagawa Y, Okuyama A. Laparoscopic nephroureterectomy for upper tract transitional cell carcinoma: comparison of laparoscopic and open surgery. Eur Urol 2006;49:332-6.

[19] Hattori R, Yoshino Y, Gotoh M, Katoh M, Kamihira O, Ono Y. Laparoscopic nephroureterectomy for transitional cell carcinoma of renal pelvis and ureter: Nagoya experience. Urology 2006;67:701-5.

[20] Okegawa T, Odagane A, Ide H, Horie S, Nutahara K, Higashihara E. Oncological outcome of retroperitoneoscopic nephroureterectomy for upper urinary tract transitional cell carcinoma. Int J Urol 2006;13:493-7.

[21] Sato $Y$, Nanbu A, Tanda $H$, et al. Comparison of surgical outcome and the systemic inflammatory response syndrome score between retroperitoneoscopic 
hand-assisted nephroureterectomy and open nephroureterectomy. Hinyokika Kiyo 2006;52:903-9.

[22] Hsueh TY, Huang YH, Chiu AW, Huan SK, Lee YH. Survival analysis in patients with upper urinary tract transitional cell carcinoma: a comparison between open and hand-assisted laparoscopic nephroureterectomy. BJU Int 2007;99:632-6.

[23] Manabe D, Saika T, Ebara S, et al. Comparative study of oncologic outcome of laparoscopic nephroureterectomy and standard nephroureterectomy for upper urinary tract transitional cell carcinoma. Urology 2007;69:457-61.

[24] Rouprêt M, Hupertan V, Sanderson KM, et al. Oncologic control after open or laparoscopic nephroureterectomy for upper urinary tract transitional cell carcinoma: a single center experience. Urology 2007;69:656-61.

[25] Lee JN, Kim HT, Kwon TG. Transperitoneal laparoscopic nephroureterectomy for upper urinary tract transitional cell carcinoma: a comparison with open nephroureterectomy. Korean J Urol 2007;48:371-5.

[26] Chung SD, Huang CY, Chueh SC, et al. Intermediate follow-up of hand-assisted retroperitoneoscopic nephroureterectomy for management of upper urinary tract urothelial carcinoma: comparison with open nephroureterectomy. Urology 2007;69:1030-4.

[27] Kong GS, Bae SR, Cho SH, Sung GT. Laparoscopic nephroureterectomy in patient with upper urinary tract transitional cell carcinoma: safety and efficacy. Korean J Urol 2007;48:252-8.

[28] Koda S, Mita K, Shigeta M, Usui T. Risk factors for intravesical recurrence following urothelial carcinoma of the upper urinary tract: no relationship to the mode of surgery. Jpn J Clin Oncol 2007;37:296-301.

[29] Nakashima K, Fujiyama C, Tokuda Y, et al. Oncologic assessment of handassisted retroperitoneoscopic nephroureterectomy for urothelial tumors of the upper tract: comparison with conventional open nephroureterectomy. J Endourol 2007;21:583-8.

[30] Müller B, Braud G, Tillou X, Karam G, Bouchot O, Rigaud J. Comparison of the oncological results of laparoscopic and open surgical total nephroureterectomy. Prog Urol 2007;17:1328-32.

[31] Taweemonkongsap T, Nualyong C, Amornvesukit T, et al. Outcomes of surgical treatment for upper urinary tract transitional cell carcinoma: comparison of retroperitoneoscopic and open nephroureterectomy. World J Surg Oncol 2008;6:3. 
[32] Hemal AK, Kumar A, Gupta NP, Seth A. Retroperitoneal nephroureterectomy with excision of cuff of the bladder for upper urinary tract transitional cell carcinoma: comparison of laparoscopic and open surgery with long-term follow-up. World J Urol 2008;26:381-6.

[33] Waldert M, Remzi M, Klingler HC, Mueller L, Marberger M. The oncological results of laparoscopic nephroureterectomy for upper urinary tract transitional cell cancer are equal to those of open nephroureterectomy. BJU Int 2009;103:66-70.

[34] Capitanio U, Shariat SF, Isbarn H, et al. Comparison of oncologic outcomes for open and laparoscopic nephroureterectomy: a multi-institutional analysis of 1249 cases. Eur Urol 2009;56:1-9.

[35] Chung SD, Chen SC, Wang SM, et al. Long-term outcome of hand-assisted laparoscopic nephroureterectomy for pathologic T3 upper urinary tract urothelial carcinoma. J Endourol 2009;23:75-80.

[36] Greco F, Wagner S, Hoda RM, Hamza A, Fornara P. Laparoscopic vs. open radical nephroureterectomy for upper urinary tract urothelial cancer: oncological outcomes and 5-year follow-up. BJU Int 2009;104:1274-8.

[37] Aguilera A, Pérez-Utrilla M, Giron M, Cansino R, Gil A, de la Peña J. Open and laparoscopic nephroureterectomy for urothelial tumors of the upper urinary tract: initial experience. Actas Urol Esp 2009;33:1078-82.

[38] Favaretto RL, Shariat SF, Chade DC, et al. Comparison between laparoscopic and open radical nephroureterectomy in a contemporary group of patients: are recurrence and disease-specific survival associated with surgical technique? Eur Urol 2010;58:645-51.

[39] Stewart GD, Humphries KJ, Cutress ML, Riddick AC, McNeill SA, Tolley DA. Long-term comparative outcomes of open versus laparoscopic nephroureterectomy for upper urinary tract urothelial-cell carcinoma after a median follow-up of 13 years*. J Endourol 2011;25:1329-35.

[40] Walton TJ, Novara G, Matsumoto K, et al. Oncological outcomes after laparoscopic and open radical nephroureterectomy: results from an international cohort. BJU Int 2011;108:406-12.

[41] Ariane MM, Colin P, Ouzzane A, et al. Assessment of oncologic control obtained after open versus laparoscopic nephroureterectomy for upper urinary tract urothelial carcinomas (UUT-UCs): results from a large French multicenter collaborative study. Ann Surg Oncol 2012;19:301-8. 
[42] Lotrecchiano G, Delle Cave A, Tripodi V, et al. Oncological outcomes of laparoscopic and open treatment (nephroureterectomy) for urothelial tumors of the upper urinary tract. Urologia 2012;79(Suppl 19):82-5.

[43] Hamada S, Ito K, Takahashi M, et al. Evaluation of clinical results in patients undergoing laparoscopic nephroureterectomy. Hinyokika Kiyo 2013;59:217-23.

[44] Fairey AS, Kassouf W, Estey E, et al. Comparison of oncological outcomes for open and laparoscopic radical nephroureterectomy: results from the Canadian Upper Tract Collaboration. BJU Int 2013;112:791-7.

[45] Izumi K, Itai S, Takahashi Y, et al. Factors predictive of oncological outcome after nephroureterectomy: comparison between laparoscopic and open procedures. Anticancer Res 2013;33:5501-6.

[46] Kitamura H, Maeda T, Tanaka T, et al. Comparison of laparoscopic, handassisted, and open surgical nephroureterectomy. JSLS 2014;18:288-93.

[47] Fang Z, Li L, Wang X, Chen W, et al. Total retroperitoneal laparoscopic nephroureterectomy with bladder-cuff resection for upper urinary tract transitional cell carcinoma. J Invest Surg 2014;27:354-9.

[48] Zou L, Zhang L, Zhang H, Jiang H, Ding Q. Comparison of post-operative intravesical recurrence and oncological outcomes after open versus laparoscopic nephroureterectomy for upper urinary tract urothelial carcinoma. World $\mathrm{J}$ Urol 2014;32:565-70.

[49] Miyazaki J, Nishiyama $H$, Fujimoto $H$, et al. Laparoscopic versus open nephroureterectomy in muscle-invasive upper tract urothelial carcinoma: subanalysis of the multi-institutional national database of the Japanese Urological Association. J Endourol 2016;30:520-5.

[50] Kim HS, Ku JH, Jeong CW, Kwak C, Kim HH. Laparoscopic radical nephroureterectomy is associated with worse survival outcomes than open radical nephroureterectomy in patients with locally advanced upper tract urothelial carcinoma. World J Urol 2016;34:859-69.

[51] Shan H, Wang X, Sun $Q$, et al. Oncologic results of retroperitoneoscopic versus open surgery for T2 upper tract urothelial carcinoma. Clin Genitourin Cancer 2015;13:568-73.

[52] Cochrane Handbook for Systematic Reviews of Interventions. http://handbook.cochrane.org

[53] Rai BP, Shelley M, Coles B, Somani B, Nabi G. Surgical management for upper 
urinary tract transitional cell carcinoma (UUT-TCC): a systematic review. BJU Int 2012;110:1426-35.

[54] Zhang S, Luo Y, Wang C, Fu SJ, Yang L. Long-term oncologic outcomes of laparoscopic nephroureterectomy versus open nephroureterectomy for upper tract urothelial carcinoma: a systematic review and meta-analysis. Peer J 2016;4:e2063.

[55] Krabbe LM, Westerman ME, Bagrodia A, et al. Surgical management of the distal ureter during radical nephroureterectomy is an independent predictor of oncological outcomes: results of a current series and a review of the literature. Urol Oncol 2014;32:54.e19-26.

[56] Xylinas E, Rink M, Cha EK, et al. Impact of distal ureter management on oncologic outcomes following radical nephroureterectomy for upper tract urothelial carcinoma. Eur Urol 2014;65:210-7.

[57] Seisen T, Granger B, Colin P, et al. A systematic review and meta-analysis of clinicopathologic factors linked to intravesical recurrence after radical nephroureterectomy to treat upper tract urothelial carcinoma. Eur Urol 2015;67:1122-33.

[58] Tinay I, Gelpi-Hammerschmidt F, Leow JJ, et al. Trends in utilisation, perioperative outcomes, and costs of nephroureterectomies in the management of upper tract urothelial carcinoma: a 10-year population-based analysis. BJU Int 2016;117:954-60.

[59] Rassweiler J, Tsivian A, Ravi Kumbar AV, et al. Oncological safety of laparoscopic surgery for urological malignancy: experience with more than 1,000 operations. J Urol 2003;169:2072-5.

[60] Seisen T, Shariat SF, Cussenot O, et al. Contemporary role of lymph node dissection at the time of radical nephroureterectomy for upper tract urothelial carcinoma. World J Urol 2017;35:535-48.

[61] Nison L, Bozzini G, Rouprêt M, Traxer O, Colin P. Clinical, ureteroscopic and photodynamic diagnosis of urothelial carcinomas of the upper tract: state-of-the art review for the yearly scientific report of the French National Association of Urology. Prog Urol 2014;24:977-86.

[62] Soria F, Shariat SF, Lerner SP, et al. Epidemiology, diagnosis, preoperative evaluation and prognostic assessment of upper-tract urothelial carcinoma (UTUC). 
World J Urol 2017;35:379-87.

[63] Yamany T, van Batavia J, Ahn J, Shapiro E, Gupta M. Ureterorenoscopy for upper tract urothelial carcinoma: how often are we missing lesions? Urology 2015;85:311-5.

[64] Tilki D, Huland H, Graefen M. Centralization and quality control of elective surgery improve outcome: aren't we ethically obliged to force the pace of creating high-volume centers? Eur Urol 2015;68:30-1.

Fig. 1 - A PRISMA flowchart describing the study selection process. PRISMA = Preferred Reporting Items for Systematic reviews and Meta-Analysis.

Fig. 2 - The RoB and confounding assessment for all included studies. CIS = carcinoma in situ; RoB = risk of bias. 


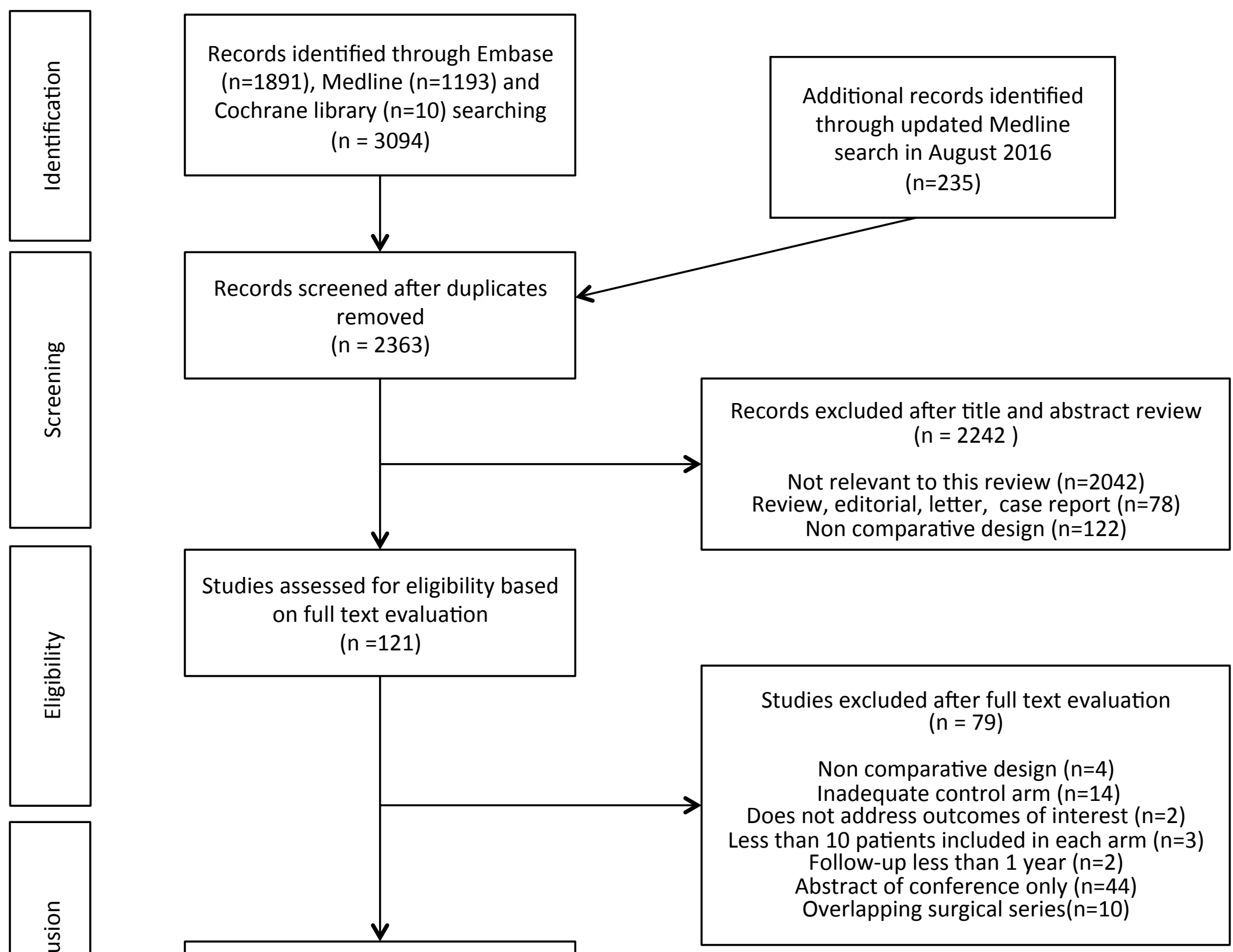

Studies included in the current systematic review

$$
(n=42)
$$




\begin{tabular}{|c|c|c|c|c|c|c|c|c|c|c|c|c|c|c|}
\hline & 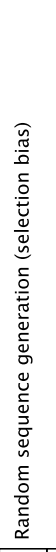 & 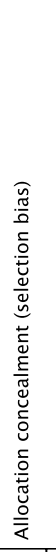 & 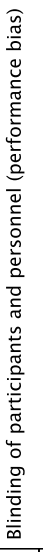 & 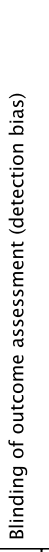 & 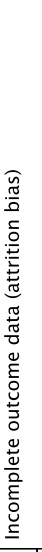 & 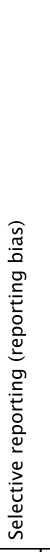 & 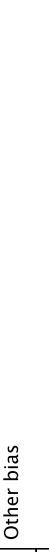 & 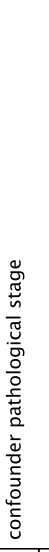 & 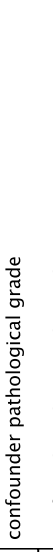 & 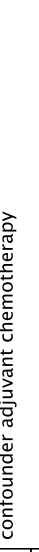 & & 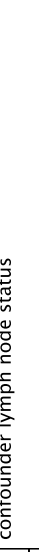 & & 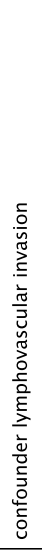 \\
\hline Aguilera et al, 2009 & e & $\theta$ & - & - & - & - & ○ & e & 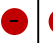 & a & 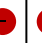 & 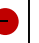 & 1 & 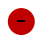 \\
\hline Ariane et al, 2012 & 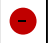 & - & - & - & - & - & $\odot$ & $\oplus$ & + & a) & + & + & 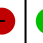 & 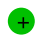 \\
\hline Capitanio et al, 2009 & $\theta$ & - & - & ○ & ○ & ○ & - & 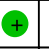 & + & ○ & + & + & $\oplus$ & + \\
\hline Chung et al, 2007 & - & - & 이 & - & • & - & $\odot$ & $\odot$ & $\odot$ & 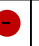 & 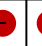 & 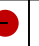 & 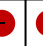 & - \\
\hline Chung et al, 2009 & $\theta$ & - & ○ & - & ○ & - & ○ & 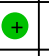 & $\theta$ & • & D & 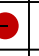 & 8 & $\theta$ \\
\hline Chung et al, J endourol 2007 & $\theta$ & - & - & - & ○ & - & $\odot$ & - & 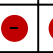 & $\partial$ & 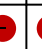 & 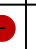 & 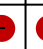 & ? \\
\hline Fairey et al, 2013 & $\theta$ & ○ & అ & అ & 인 & - & 인 & 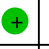 & $\oplus$ & + & D & + & + & ○ \\
\hline Fang et al, 2014 & - & $\odot$ & ○ & $\odot$ & - & - & - & $\odot$ & - & 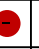 & 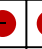 & $\theta$ & 8 & $\odot$ \\
\hline Favaretto et al, Eur Urol 2010 & $\theta$ & - & ○ & ? & ○ & - & ○ & - & $\ominus$ & P & ? & ? & 8 & ? \\
\hline Gill et al, 2000 & $\theta$ & $\ominus$ & ? & $\ominus$ & ○ & ○ & $\ominus$ & $\odot$ & 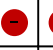 & 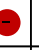 & 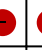 & ? & 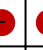 & ? \\
\hline Greco et al, 2009 & - & - & - & - & - & 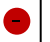 & $\ominus$ & - & - & 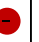 & $\Rightarrow$ & 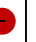 & 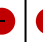 & - \\
\hline Hamada et al, 2013 & $\theta$ & ○ & ? & ○) & ○) & ○ & ○ & ○) & $\theta$ & $\theta$ & 8 & 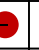 & 5 & $\theta$ \\
\hline Hattori et al, 2006 & 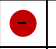 & $\odot$ & 인 & $\odot$ & - & $\boldsymbol{\ominus}$ & అ & ㄹ. & అ & 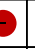 & $\theta$ & 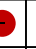 & 8 & 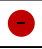 \\
\hline Hemal et al, 2008 & - & ○ & 인 & ○ & ○ & ○ & ○ & $\odot$ & 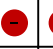 & $\theta$ & 8 & $\partial$ & 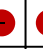 & $\theta$ \\
\hline Hsueh et al, 2007 & - & $\odot$ & 인 & - & ○ & $\boldsymbol{\theta}$ & - & $\oplus$ & $\oplus$ & 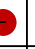 & 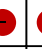 & 2 & 8 & $\ominus$ \\
\hline Izumi et al, 2013 & అ & - & ○ & ? & - & ○ & ○ & - & ○ & 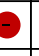 & O & 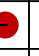 & 8 & ? \\
\hline Kawauchi et al, 2002 & $\theta$ & - & - & ○ & - & • & - & ○ & 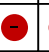 & $\theta$ & D & 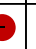 & D & ? \\
\hline Kim et al, 2005 & అ & ? & - & ? & ○ & ○ & ○ & $\ominus$ & $\odot$ & P & 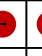 & P & 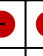 & ? \\
\hline Kim et al, 2015 & ○ & ○ & 인 & 인 & 인 & ○ & 인 & $\oplus$ & $\oplus$ & 2 & \pm & 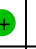 & + & + \\
\hline Kitamura et al, 2014 & $\theta$ & ? & ? & ? & ○) & ? & $\odot$ & - & ○ & $\partial$ & 2 & 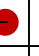 & 2 & ? \\
\hline Koda et al, 2007 & $\theta$ & ○ & • & $\ominus$ & 이 & ○ & ○ & 인 & ○ & ? & r & 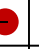 & S & ○ \\
\hline Kong et al, 2007 & 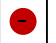 & - & - & - & - & - & $\odot$ & - & - & 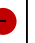 & D & 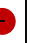 & 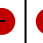 & $\Theta$ \\
\hline Lee et al, 2007 & $\theta$ & ○ & అ & ○ & • & 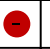 & ○ & ○ & ○ & D & 5 & 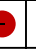 & 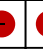 & ? \\
\hline Lotrecchiano et al, 2012 & $\theta$ & $\odot$ & 인 & $\odot$ & ○ & $\boldsymbol{\ominus}$ & $\odot$ & $\odot$ & - & 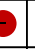 & 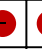 & $\partial$ & 8 & $\odot$ \\
\hline Manabe et al, 2007 & $\theta$ & $\ominus$ & 이 & $\ominus$ & 인 & ○ & ? & 인 & 인 & a & D & 2 & S & $\theta$ \\
\hline Miyazaki et al, 2015 & $\odot$ & 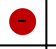 & • & - & ○ & ○ & ○ & + & $\ominus$ & ○ & ? & 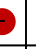 & 8 & $\odot$ \\
\hline Muller et al, 2007 & అ & - & $\Theta$ & - & - & - & $\odot$ & అ & అ & P) & D & 9 & 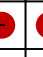 & - \\
\hline Nakashima et al, 2007 & $\theta$ & $\theta$ & - & $\boldsymbol{\ominus}$ & - & అ & - & 인 & - & 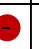 & $\Rightarrow$ & 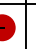 & 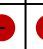 & ? \\
\hline Okegawa et al, 2006 & - & - & ○ & ? & ○) & $\boldsymbol{\theta}$ & అ & - & అ & $\theta$ & D & 2 & 8 & ? \\
\hline Raman et al, 2006 & $\theta$ & $\theta$ & 인 & ○ & - & అ & ○ & $\odot$ & - & $\theta$ & D & 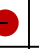 & 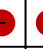 & $\theta$ \\
\hline Rouprêt et al, 2007 & $\theta$ & - & - & - & • & - & ○ & 안 & $\Theta$ & a & D & 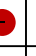 & 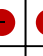 & ? \\
\hline Satto et al, 2006 & $\theta$ & $\theta$ & ○ & $\ominus$ & ○ & ○ & 인 & 인 & • & (2) & 8 & 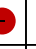 & 8 & $\ominus$ \\
\hline Shalav et al, 2000 & $\theta$ & - & - & - & ○ & - & $\odot$ & అ & - & D & $\Rightarrow$ & D & 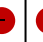 & - \\
\hline Shan et al, 2015 & $\theta$ & - & ○ & - & - & ○ & ○ & ○ & ○) & 2 & 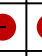 & 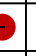 & 8 & ? \\
\hline Simone et al, 2009 & $\oplus$ & 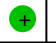 & - & ๑ & $\oplus$ & $\oplus$ & + & $\oplus$ & + & + & $\oplus$ & + & $\oplus$ & 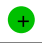 \\
\hline Stewart et al, 2011 & - & ○ & - & - & ○ & - & ○ & • & - & (2) & 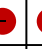 & 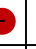 & S & $\ominus$ \\
\hline Stifelman et al, 2001 & $\odot$ & 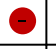 & • & - & 인 & ○ & () & • & - & P & D & 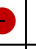 & 8 & $\odot$ \\
\hline Taweemonkongsap et al, 2008 & - & 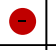 & ○ & 울 & 울 & 을 & 인 & $\oplus$ & $\oplus$ & 2 & D & 2 & $\vec{\theta}$ & $\odot$ \\
\hline Tsujihata et al, 2006 & $\theta$ & $\odot$ & అ & ○ & - & ○ & O & అ| & - & 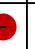 & 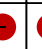 & 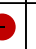 & 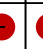 & ? \\
\hline Waldert et al, 2008 & $\theta$ & - & - & అ & $\ominus$ & - & () & + & + & 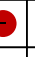 & 2 & + & 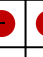 & ? \\
\hline Walton et al, 2011 & $\theta$ & ○ & అ| & $\Theta$ & 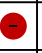 & $\theta$ & O & + & + & t & + & + & +5 & + \\
\hline Zou et al, 2014 & $\odot$ & 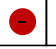 & - & - & 리 & - & - & $\oplus$ & $\oplus$ & ol & 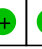 & + & + & 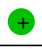 \\
\hline
\end{tabular}


Table 1 - Characteristics of included studies

\begin{tabular}{|c|c|c|c|c|c|c|c|c|c|c|c|c|c|}
\hline Study & Year & Study design & LE & $\begin{array}{c}\text { Surgical } \\
\text { approaches }\end{array}$ & $\begin{array}{l}\text { Numb } \\
\text { er of } \\
\text { patien } \\
\text { ts }\end{array}$ & Surgical route & $\begin{array}{l}\text { Bladder cuff } \\
\text { excision }\end{array}$ & $\begin{array}{l}\text { Median } \\
\text { follow- } \\
\text { up (mo) }\end{array}$ & $\begin{array}{l}\text { Pathologi } \\
\text { cal grade }\end{array}$ & $\begin{array}{l}\geq \mathrm{pT} \\
3 \\
\text { stag } \\
e \\
(\%)\end{array}$ & $\begin{array}{l}\text { No } \\
\text { lymph } \\
\text { node } \\
\text { dissecti } \\
\text { on (\%) }\end{array}$ & $\begin{array}{c}\mathrm{pN}+ \\
\text { stag } \\
e \\
(\%)\end{array}$ & $\begin{array}{c}\text { Positi } \\
\text { ve } \\
\text { surgic } \\
\text { al } \\
\text { margi } \\
\text { ns } \\
(\%) \\
\end{array}$ \\
\hline \multicolumn{14}{|c|}{ Combined laparoscopic RNU vs open RNU } \\
\hline \multirow[t]{2}{*}{$\begin{array}{l}\text { Kawauchi } \\
\text { et al [16] }\end{array}$} & 2002 & $\begin{array}{l}\text { Single-centre } \\
\text { retrospective }\end{array}$ & 3 & Open & 34 & $\begin{array}{c}\text { Transperitoneal: } \\
18 \% \\
\text { Retroperitoneal: } \\
82 \%\end{array}$ & $\begin{array}{c}\text { Stripping: } 21 \% \\
\text { NR: } 79 \%\end{array}$ & $\begin{array}{l}\text { Mean: } \\
48.8\end{array}$ & $\begin{array}{c}\text { G1: } \\
11.8 \% \\
\text { G2: } 50 \% \\
\text { G3: } \\
38.2 \%\end{array}$ & 38.2 & NR & NR & NR \\
\hline & & & & $\begin{array}{l}\text { Laparoscopic } \\
\text { hand assisted }\end{array}$ & 34 & Retroperitoneal & $\begin{array}{c}\text { Open } \\
\text { extravesical: } 92 \% \\
\text { Endoscopic: } 8 \%\end{array}$ & $\begin{array}{l}\text { Mean: } \\
48.8\end{array}$ & $\begin{array}{c}\text { G1: } \\
\text { 14.7\% } \\
\text { G2: } \\
58.8 \% \\
\text { G3: } \\
26.5 \%\end{array}$ & 35.3 & NR & NR & NR \\
\hline \multirow[t]{2}{*}{$\begin{array}{l}\text { Okegawa } \\
\text { et al [20] }\end{array}$} & 2006 & $\begin{array}{l}\text { Single-centre } \\
\text { retrospective }\end{array}$ & 3 & Open & 24 & NR & NR & $\begin{array}{l}\text { Mean: } \\
29.2\end{array}$ & $\begin{array}{c}\text { G1: } 4.3 \% \\
\text { G2: } \\
65.2 \% \\
\text { G3: } \\
30.4 \%\end{array}$ & 21.7 & NR & NR & NR \\
\hline & & & & Laparoscopic & 25 & Retroperitoneal & $\begin{array}{c}\text { Open } \\
\text { extravesical }\end{array}$ & $\begin{array}{l}\text { Mean: } \\
24.3\end{array}$ & $\begin{array}{l}\text { G1: } 8 \% \\
\text { G2: } 68 \% \\
\text { G3: } 24 \%\end{array}$ & 16 & NR & NR & NR \\
\hline \multirow[t]{2}{*}{$\begin{array}{l}\text { Sato et al } \\
\text { [21] }\end{array}$} & 2006 & $\begin{array}{l}\text { Single-centre } \\
\text { retrospective }\end{array}$ & 3 & Open & 23 & NR & $\begin{array}{c}\text { Open } \\
\text { extravesical }\end{array}$ & 60 & $\begin{array}{c}\text { G1: } \\
21.7 \% \\
\text { G2: } \\
60.9 \% \\
\text { G3: } \\
17.4 \%\end{array}$ & 30.4 & NR & 4.3 & NR \\
\hline & & & & $\begin{array}{l}\text { Laparoscopic } \\
\text { hand assisted }\end{array}$ & 36 & NR & $\begin{array}{c}\text { Open } \\
\text { extravesical }\end{array}$ & 25 & $\begin{array}{c}\text { G1: } \\
16.7 \% \\
\text { G2: } \\
66.6 \% \\
\text { G3: } \\
16.7 \%\end{array}$ & 33.4 & NR & 2.8 & NR \\
\hline $\begin{array}{l}\text { Rouprêt et } \\
\text { al [24] }\end{array}$ & 2007 & $\begin{array}{l}\text { Single-centre } \\
\text { retrospective }\end{array}$ & 3 & Open & 26 & NR & NR & $\begin{array}{l}\text { Mean: } \\
\quad 78\end{array}$ & $\begin{array}{l}\text { Low } \\
\text { grade: } \\
26.9 \% \\
\text { High } \\
\text { grade: }\end{array}$ & 38.4 & NR & 19.2 & 0 \\
\hline
\end{tabular}




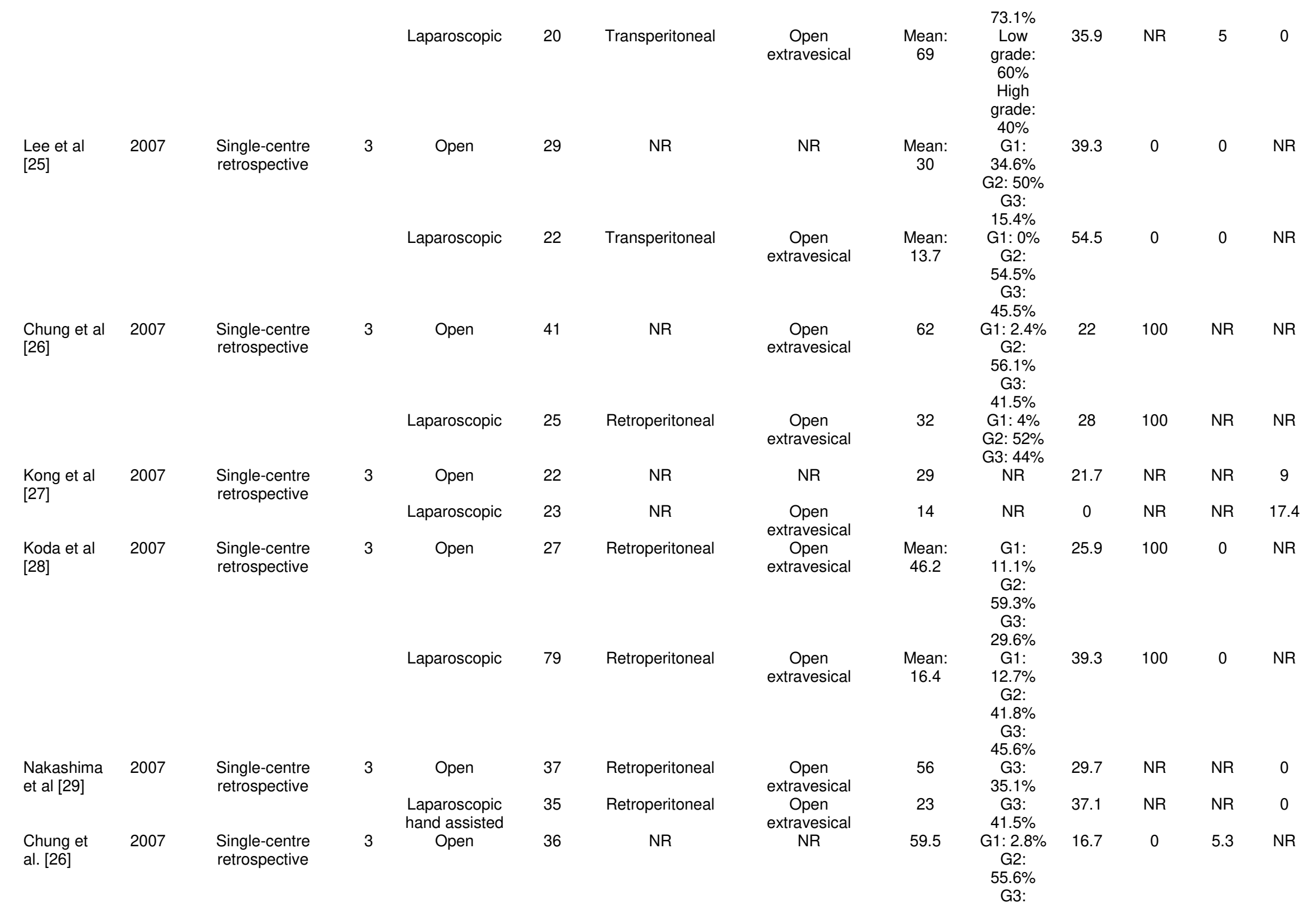




\begin{tabular}{|c|c|c|c|c|c|c|c|c|c|c|c|c|c|}
\hline & & & & Laparoscopic & 39 & Transperitoneal & $\begin{array}{c}\text { Open } \\
\text { extravesical }\end{array}$ & 48 & $\begin{array}{c}41.7 \% \\
\text { G1: } 2.6 \% \\
\text { G2: } \\
56.4 \% \\
\text { G3: } 41 \%\end{array}$ & 30.8 & 0 & 10.5 & NR \\
\hline \multirow[t]{2}{*}{$\begin{array}{l}\text { Taweemon } \\
\text { kongsap et } \\
\text { al [31] }\end{array}$} & 2008 & $\begin{array}{l}\text { Single-centre } \\
\text { retrospective }\end{array}$ & 3 & Open & 29 & Retroperitoneal & $\begin{array}{c}\text { Open } \\
\text { extravesical }\end{array}$ & $\begin{array}{l}\text { Mean: } \\
26.4\end{array}$ & $\begin{array}{l}\text { Low } \\
\text { grade: } \\
34.5 \% \\
\text { High } \\
\text { grade: } \\
65.5 \%\end{array}$ & 13.8 & 70 & 10.3 & NR \\
\hline & & & & Laparoscopic & 31 & Retroperitoneal & $\begin{array}{c}\text { Open } \\
\text { extravesical }\end{array}$ & $\begin{array}{l}\text { Mean: } \\
27.9\end{array}$ & $\begin{array}{l}\text { Low } \\
\text { grade: } \\
58.1 \% \\
\text { High } \\
\text { grade: } \\
41.9 \%\end{array}$ & 16.1 & 35.5 & 3.2 & NR \\
\hline \multirow[t]{2}{*}{$\begin{array}{l}\text { Waldert et } \\
\text { al [33] }\end{array}$} & 2008 & $\begin{array}{l}\text { Single-centre } \\
\text { retrospective }\end{array}$ & 3 & Open & 59 & Retroperitoneal & Open intravesical & $\begin{array}{l}\text { Mean: } \\
41\end{array}$ & $\begin{array}{c}\text { G1: } 6.8 \% \\
\text { G2: } \\
52.5 \% \\
\text { G3: } \\
40.7 \%\end{array}$ & 33.9 & 20.3 & 10.2 & 0 \\
\hline & & & & Laparoscopic & 43 & NR & Open intravesical & $\begin{array}{l}\text { Mean: } \\
41\end{array}$ & $\begin{array}{c}\text { G1: } \\
\text { 13.9\% } \\
\text { G2: } \\
44.2 \% \\
\text { G3: } \\
41.9 \%\end{array}$ & 41.9 & 30.2 & 16.3 & 0 \\
\hline \multirow[t]{2}{*}{$\begin{array}{l}\text { Chung et al } \\
\text { [35] }\end{array}$} & 2009 & $\begin{array}{l}\text { Single-centre } \\
\text { retrospective } \\
\text { matched paired } \\
\text { comparison }\end{array}$ & 3 & Open & 31 & Retroperitoneal & $\begin{array}{c}\text { Open } \\
\text { extravesical }\end{array}$ & 115 & $\begin{array}{c}\text { G1: } \\
22.6 \% \\
\text { G2: } \\
32.2 \% \\
\text { G3: } \\
45.2 \%\end{array}$ & 100 & 0 & 0 & NR \\
\hline & & & & $\begin{array}{l}\text { Laparoscopic } \\
\text { hand assisted }\end{array}$ & 21 & Transperitoneal & $\begin{array}{l}\text { Open } \\
\text { extravesical }\end{array}$ & 72 & $\begin{array}{c}\text { G1: } 0 \% \\
\text { G2: } \\
\text { 42.9\% } \\
\text { G3: } \\
57.1 \%\end{array}$ & 100 & 0 & 0 & NR \\
\hline \multirow[t]{2}{*}{$\begin{array}{l}\text { Ariane et al } \\
\text { [41] }\end{array}$} & 2011 & $\begin{array}{l}\text { Multicentre } \\
\text { retrospective }\end{array}$ & 3 & Open & 459 & NR & $\begin{array}{c}\text { Open } \\
\text { extravesical: } 96 \% \\
\text { Stripping: } 4 \%\end{array}$ & 27 & $\begin{array}{c}\text { G1: } 8.5 \% \\
\text { G2: } \\
36.2 \% \\
\text { G3: } \\
55.3 \%\end{array}$ & 39.6 & 52.5 & 10.2 & NR \\
\hline & & & & Laparoscopic & 150 & Transperitoneal & $\begin{array}{c}\text { Open } \\
\text { extravesical: } 95 \% \\
\text { Stripping: } 5 \%\end{array}$ & NR & $\begin{array}{c}\text { G1: } 7.3 \% \\
\text { G2: } \\
27.3 \% \\
\text { G3: } \\
65.3 \%\end{array}$ & 36.6 & 70 & 4.7 & NR \\
\hline
\end{tabular}




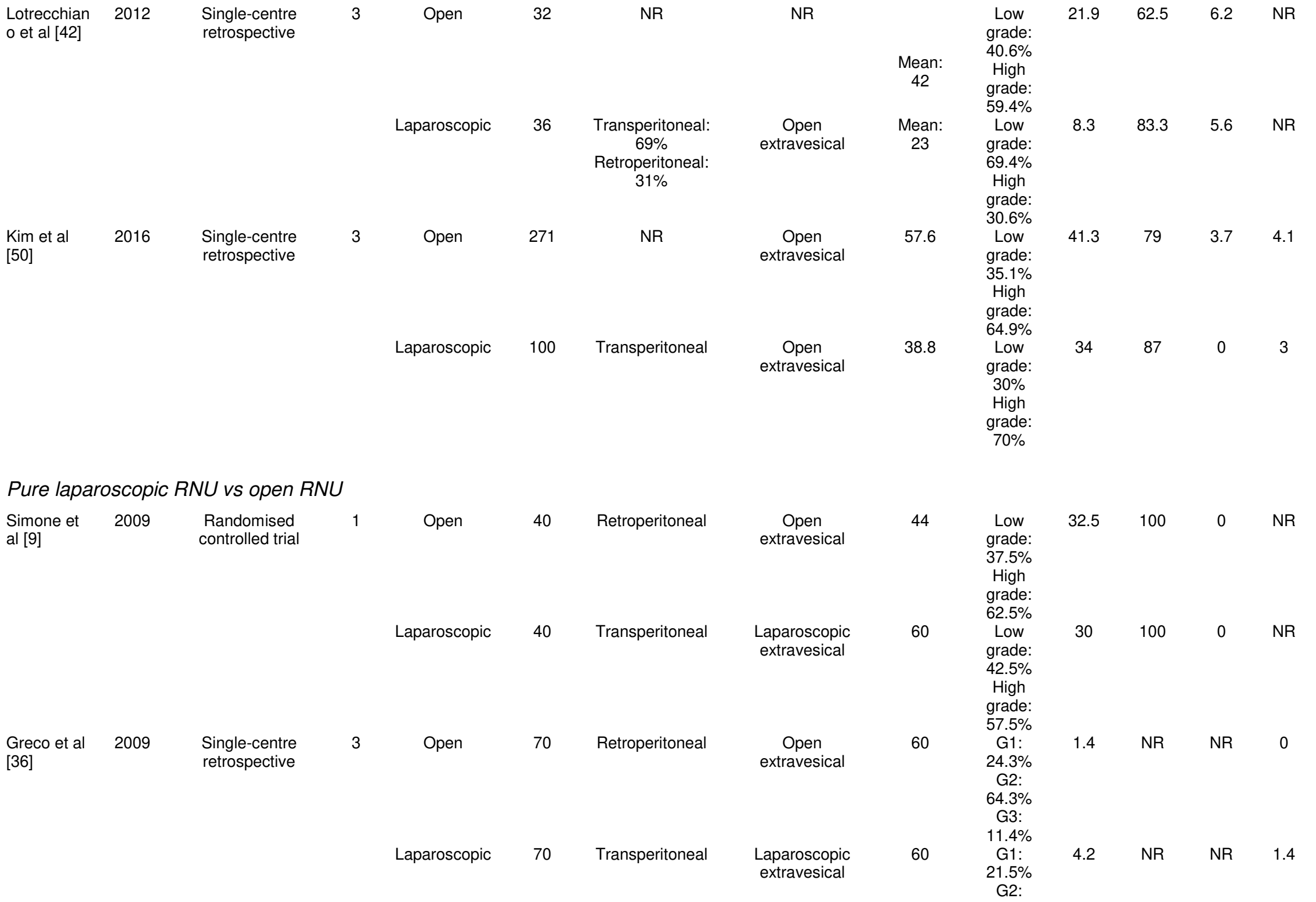




\begin{tabular}{|c|c|c|c|c|c|c|c|c|c|c|c|c|c|}
\hline \multirow{2}{*}{$\begin{array}{l}\text { Fang et al } \\
{[47]}\end{array}$} & \multirow[t]{2}{*}{2014} & \multirow{2}{*}{$\begin{array}{l}\text { Single-centre } \\
\text { retrospective }\end{array}$} & \multirow[t]{2}{*}{3} & Open & 36 & NR & NR & Mean: & $\begin{array}{c}11.4 \% \\
\text { NR }\end{array}$ & NR & NR & NR & NR \\
\hline & & & & Laparoscopic & 29 & Retroperitoneal & $\begin{array}{l}\text { Laparoscopic } \\
\text { extravesical }\end{array}$ & $\begin{array}{l}\text { Mean: } \\
22.4\end{array}$ & NR & NR & NR & NR & NR \\
\hline \multicolumn{14}{|c|}{ Unspecified/heterogeneous laparoscopic vs open RNU } \\
\hline \multirow[t]{2}{*}{$\begin{array}{l}\text { Kim et al } \\
{[17]}\end{array}$} & \multirow[t]{2}{*}{2005} & \multirow[t]{2}{*}{$\begin{array}{l}\text { Single-centre } \\
\text { retrospective }\end{array}$} & \multirow[t]{2}{*}{3} & Open & 17 & NR & NR & $\begin{array}{l}\text { Mean: } \\
25.6\end{array}$ & NR & NR & NR & NR & NR \\
\hline & & & & Laparoscopic & 10 & NR & NR & $\begin{array}{l}\text { Mean: } \\
19\end{array}$ & $\begin{array}{l}\text { G1: } 10 \% \\
\text { G2: } 60 \% \\
\text { G3: } 30 \%\end{array}$ & 20 & 0 & 10 & NR \\
\hline \multirow[t]{2}{*}{$\begin{array}{l}\text { Tsujihata et } \\
\text { al [18] }\end{array}$} & \multirow[t]{2}{*}{2006} & \multirow[t]{2}{*}{$\begin{array}{l}\text { Single-centre } \\
\text { retrospective }\end{array}$} & \multirow[t]{2}{*}{3} & Open & 24 & NR & NR & 22.1 & $\begin{array}{c}\text { G1: } 4.2 \% \\
\text { G2: } \\
45.8 \% \\
\text { G3: } 50 \%\end{array}$ & 16.7 & 0 & 0 & NR \\
\hline & & & & Laparoscopic & 25 & Retroperitoneal & NR & 22.4 & $\begin{array}{l}\text { G1: } 20 \% \\
\text { G2: } 60 \% \\
\text { G3: } 20 \%\end{array}$ & 8 & 0 & 0 & NR \\
\hline \multirow[t]{2}{*}{$\begin{array}{l}\text { Hattori et al } \\
\text { [19] }\end{array}$} & \multirow[t]{2}{*}{2006} & \multirow[t]{2}{*}{$\begin{array}{l}\text { Single-centre } \\
\text { retrospective }\end{array}$} & \multirow[t]{2}{*}{3} & Open & 60 & NR & NR & 35 & $\begin{array}{c}\text { G1: } 10 \% \\
\text { G2: } \\
51.7 \% \\
\text { G3: } \\
38.3 \%\end{array}$ & 38.3 & NR & 12 & NR \\
\hline & & & & Laparoscopic & 89 & Retroperitoneal & $\begin{array}{c}\text { Open } \\
\text { extravesical: } 40 \% \\
\text { Laparoscopic } \\
\text { extravesical: } 60 \%\end{array}$ & 31 & $\begin{array}{c}\text { G1: } \\
15.7 \% \\
\text { G2: } \\
53.5 \% \\
\text { G3: } \\
34.8 \%\end{array}$ & 30.3 & NR & 13.5 & NR \\
\hline \multirow[t]{2}{*}{$\begin{array}{l}\text { Raman et } \\
\text { al [5] }\end{array}$} & \multirow[t]{2}{*}{2006} & \multirow[t]{2}{*}{$\begin{array}{l}\text { Single-centre } \\
\text { retrospective }\end{array}$} & \multirow[t]{2}{*}{3} & Open & 38 & Retroperitoneal & $\begin{array}{c}\text { Open } \\
\text { extravesical: } 61 \% \\
\text { Open } \\
\text { intravesical: } 39 \%\end{array}$ & $\begin{array}{l}\text { Mean: } \\
51\end{array}$ & $\begin{array}{c}\text { Low } \\
\text { grade: } \\
63.5 \% \\
\text { High } \\
\text { grade: } \\
36.5 \%\end{array}$ & NR & NR & NR & NR \\
\hline & & & & $\begin{array}{l}\text { Laparoscopic } \\
\text { hand assisted }\end{array}$ & 52 & Transperitoneal & $\begin{array}{c}\text { Open } \\
\text { extravesical: } 58 \% \\
\text { Open } \\
\text { intravesical: } 21 \% \\
\text { Endoscopic: } 21 \%\end{array}$ & $\begin{array}{l}\text { Mean : } \\
31.7\end{array}$ & $\begin{array}{c}\text { Low } \\
\text { grade: } \\
60.5 \% \\
\text { High } \\
\text { grade: } \\
39.5 \%\end{array}$ & NR & NR & $N R$ & NR \\
\hline $\begin{array}{l}\text { Hsueh et al } \\
\text { [22] }\end{array}$ & 2007 & $\begin{array}{l}\text { Multicentre } \\
\text { retrospective }\end{array}$ & 3 & Open & 77 & NR & NR & $\begin{array}{l}\text { Mean: } \\
53.6\end{array}$ & $\begin{array}{c}\text { G1: } 3.9 \% \\
\text { G2: } \\
50.6 \%\end{array}$ & 22.1 & NR & NR & NR \\
\hline
\end{tabular}




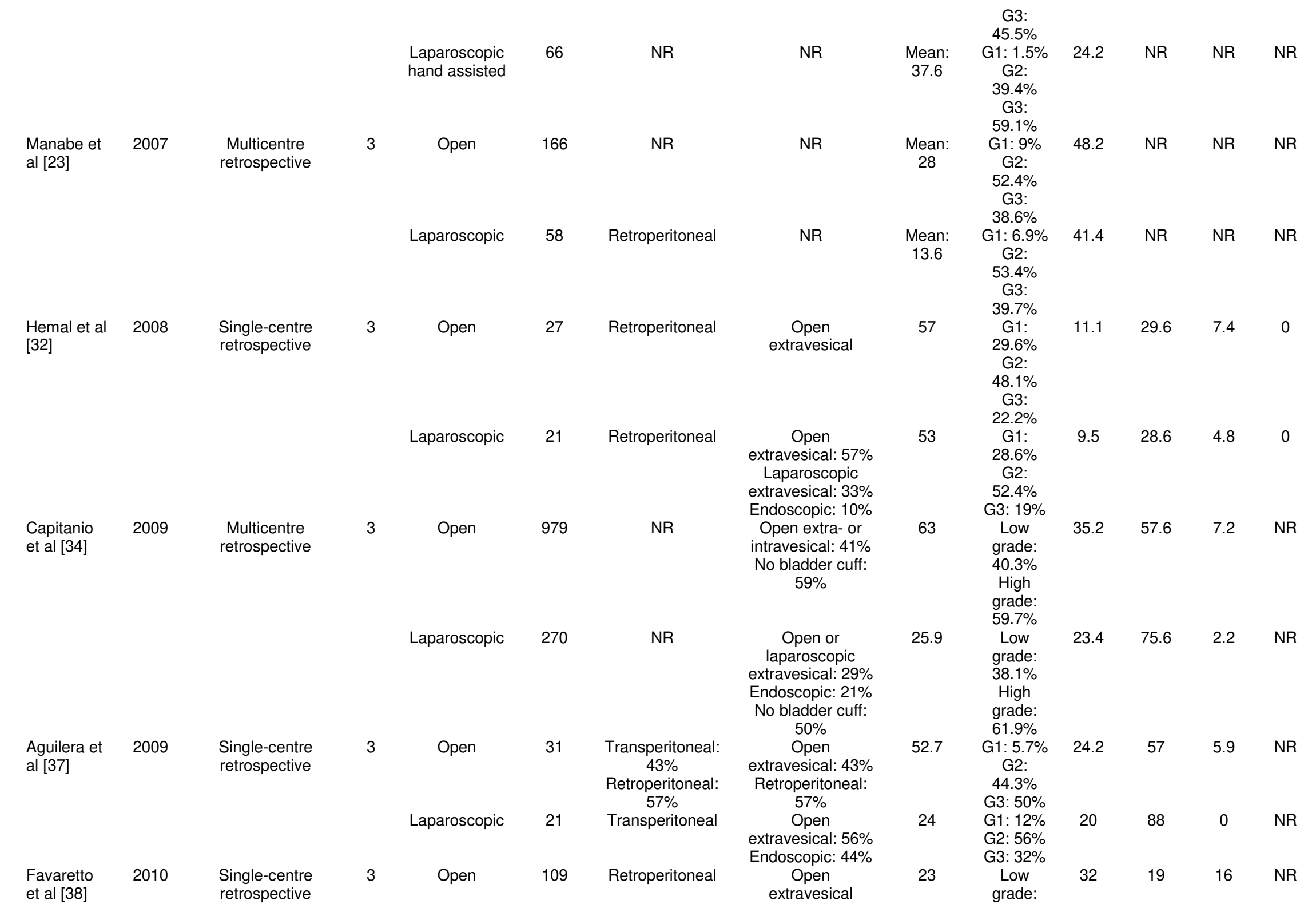




\begin{tabular}{|c|c|c|c|c|c|c|c|c|c|c|c|c|c|}
\hline & & & & & & & & & $\begin{array}{c}12 \% \\
\text { High } \\
\text { grade: } \\
86 \%\end{array}$ & & & & \\
\hline & & & & Laparoscopic & 53 & $\begin{array}{c}\text { Transperitoneal: } \\
66 \% \\
\text { Retroperitoneal: } \\
34 \%\end{array}$ & $\begin{array}{c}\text { Open } \\
\text { extravesical: } 75 \% \\
\text { Laparoscopic } \\
\text { extravesical: } 21 \% \\
\text { Endoscopic: } 4 \%\end{array}$ & 17 & $\begin{array}{c}\text { Low } \\
\text { grade: } \\
9 \% \\
\text { High } \\
\text { grade: } \\
87 \%\end{array}$ & 32 & 30 & 13 & NR \\
\hline \multirow[t]{2}{*}{$\begin{array}{l}\text { Stewart et } \\
\text { al [39] }\end{array}$} & 2011 & $\begin{array}{l}\text { Single-centre } \\
\text { retrospective }\end{array}$ & 3 & Open & 39 & Transperitoneal & NR & 177 & $\begin{array}{c}\text { G1: } \\
\text { 10.2\% } \\
\text { G2: } \\
51.2 \% \\
\text { G3: } \\
38.5 \%\end{array}$ & 23.1 & NR & NR & NR \\
\hline & & & & Laparoscopic & 23 & Transperitoneal & NR & 146 & $\begin{array}{c}\text { G1: } 13 \% \\
\text { G2: } \\
30.4 \% \\
\text { G3: } \\
56.5 \%\end{array}$ & 13 & NR & NR & NR \\
\hline \multirow[t]{2}{*}{$\begin{array}{l}\text { Walton et } \\
\text { al [40] }\end{array}$} & 2011 & $\begin{array}{l}\text { Multicentre } \\
\text { retrospective }\end{array}$ & 3 & Open & 703 & NR & $\begin{array}{c}\text { Endoscopic: } 13 \% \\
\text { NR: } 87 \%\end{array}$ & 36 & $\begin{array}{c}\text { G1: } \\
\text { 12.4\% } \\
\text { G2: } \\
31.2 \% \\
\text { G3: } \\
56.3 \%\end{array}$ & 33.6 & 77 & 6.8 & NR \\
\hline & & & & Laparoscopic & 70 & NR & NR & 17 & $\begin{array}{c}\text { G1: } \\
15.7 \% \\
\text { G2: } 7.1 \% \\
\text { G3: } \\
77.1 \%\end{array}$ & 32.8 & $70 \%$ & $\begin{array}{l}2.9 \\
\%\end{array}$ & NR \\
\hline \multirow[t]{2}{*}{$\begin{array}{l}\text { Hamada et } \\
\text { al [43] }\end{array}$} & 2013 & $\begin{array}{l}\text { Single-centre } \\
\text { retrospective }\end{array}$ & 3 & Open & 50 & $\begin{array}{c}\text { Transperitoneal: } \\
32 \% \\
\text { Retroperitoneal: } \\
68 \%\end{array}$ & NR & NR & $\begin{array}{c}\text { G1: } 4 \% \\
\text { G2: } 34 \% \\
\text { G3: } 62 \%\end{array}$ & 41.2 & NR & 6 & NR \\
\hline & & & & Laparoscopic & 55 & NR & NR & NR & $\begin{array}{l}\text { G1: } 2 \% \\
\text { G2: } 32 \% \\
\text { G3: } 66 \%\end{array}$ & 46 & NR & 0 & NR \\
\hline $\begin{array}{l}\text { Fairey et al } \\
\text { [44] }\end{array}$ & 2013 & $\begin{array}{l}\text { Multicentre } \\
\text { retrospective }\end{array}$ & 3 & Open & 403 & NR & $\begin{array}{c}\text { Open } \\
\text { extravesical: } 42 \% \\
\text { Open } \\
\text { intravesical: } 51 \% \\
\text { Endoscopic: } 4 \% \\
\text { NR: } 3 \%\end{array}$ & 26 & $\begin{array}{c}\text { Low } \\
\text { grade: } \\
31 \% \\
\text { High } \\
\text { grade: } \\
69 \%\end{array}$ & 31 & 68 & 10 & 11 \\
\hline
\end{tabular}




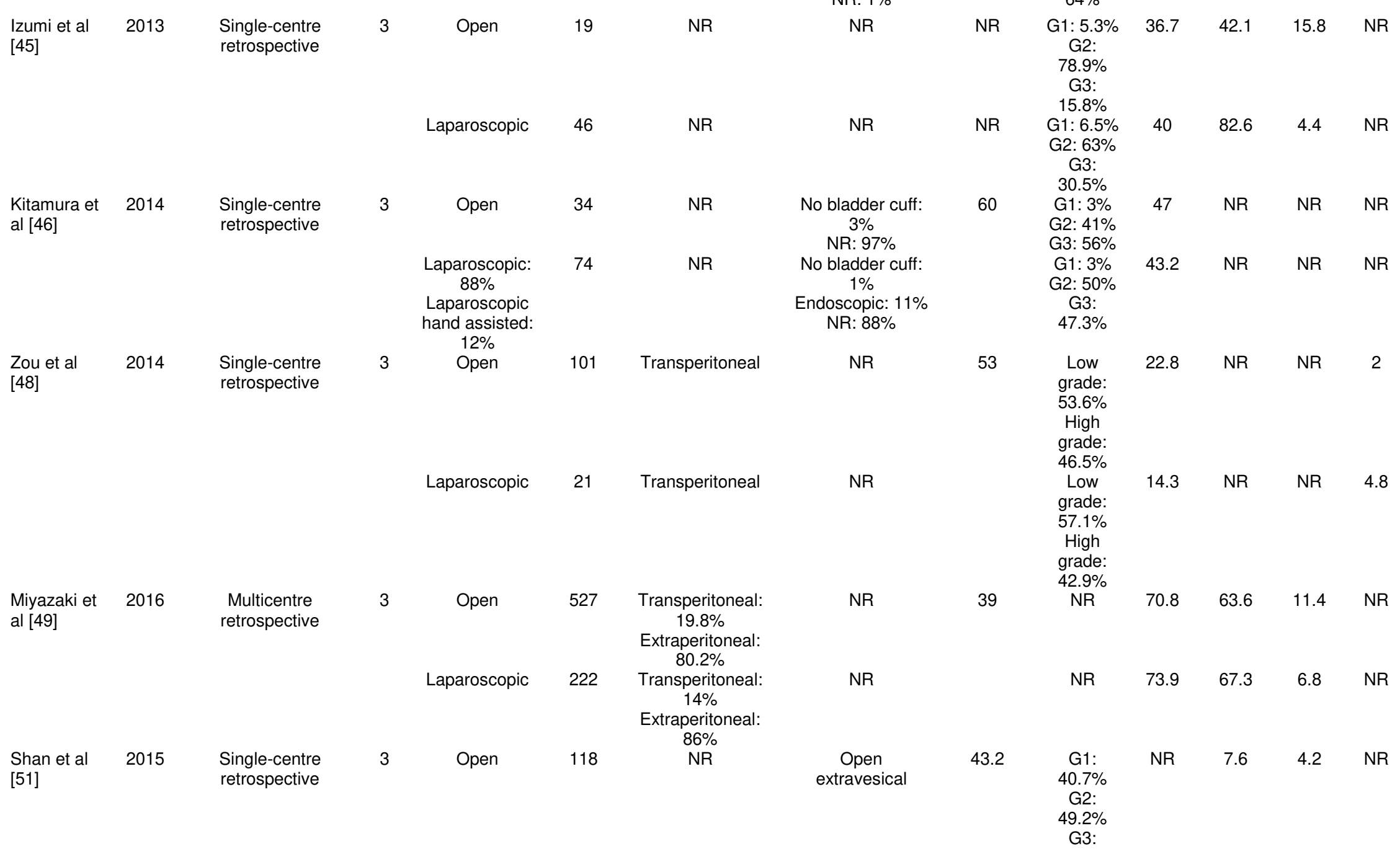




\begin{tabular}{|c|c|c|c|c|c|c|c|c|c|c|c|c|c|}
\hline & & & & Laparoscopic & 100 & Retroperitoneal & $\begin{array}{c}\text { Open } \\
\text { extravesical: } \\
67.3 \% \\
\text { Endoscopic: } \\
32.7 \%\end{array}$ & & $\begin{array}{c}10.1 \% \\
\text { G1: } \\
36.4 \% \\
\text { G2: } \\
50.9 \% \\
\text { G3: } \\
12.7 \%\end{array}$ & NR & 10.9 & 2.7 & NR \\
\hline \multicolumn{14}{|c|}{ Laparoscopic RNU with endoscopic bladder cuff excision vs open RNU } \\
\hline \multirow[t]{2}{*}{$\begin{array}{l}\text { Shalhav et } \\
\text { al [13] }\end{array}$} & 2000 & $\begin{array}{l}\text { Single-centre } \\
\text { retrospective }\end{array}$ & 3 & Open & 17 & NR & NR & $\begin{array}{l}\text { Mean: } \\
43\end{array}$ & $\begin{array}{l}\text { G1: } 29 \% \\
\text { G2: } 47 \% \\
\text { G3: } 24 \%\end{array}$ & NR & NR & NR & NR \\
\hline & & & & Laparoscopic & 25 & Transperitoneal & $\begin{array}{l}\text { Endoscopic: } 96 \% \\
\text { Stripping: } 4 \%\end{array}$ & $\begin{array}{l}\text { Mean: } \\
24\end{array}$ & $\begin{array}{l}\text { G1: } 48 \% \\
\text { G2: } 24 \% \\
\text { G3: } 28 \%\end{array}$ & NR & NR & NR & NR \\
\hline \multirow[t]{2}{*}{$\begin{array}{l}\text { Gill et al } \\
{[14]}\end{array}$} & 2000 & $\begin{array}{l}\text { Single-centre } \\
\text { retrospective }\end{array}$ & 3 & Open & 35 & NR & NR & $\begin{array}{l}\text { Mean: } \\
34.4\end{array}$ & $\begin{array}{c}\text { G1: } 17 \% \\
\text { G2: } 29 \% \\
\text { G3: } 46 \% \\
\text { Unknown } \\
: 8 \%\end{array}$ & 23 & NR & 3 & 15 \\
\hline & & & & Laparoscopic & 42 & Retroperitoneal & Endoscopic & $\begin{array}{l}\text { Mean: } \\
11.1\end{array}$ & $\begin{array}{l}\text { G1:21\% } \\
\text { G2: } 24 \% \\
\text { G3: } 55 \%\end{array}$ & 22 & NR & 5 & 7 \\
\hline \multirow[t]{2}{*}{$\begin{array}{l}\text { Stifelman } \\
\text { et al [15] }\end{array}$} & 2001 & $\begin{array}{l}\text { Single-centre } \\
\text { retrospective }\end{array}$ & 3 & Open & 11 & Retroperitoneal & NR & $\begin{array}{l}\text { Mean: } \\
17\end{array}$ & $\begin{array}{c}\text { Low } \\
\text { grade: } \\
9 \% \\
\text { High } \\
\text { grade: } \\
91 \%\end{array}$ & NR & NR & NR & 9 \\
\hline & & & & $\begin{array}{l}\text { Laparoscopic } \\
\text { hand assisted }\end{array}$ & 11 & Transperitoneal & Endoscopic & $\begin{array}{l}\text { Mean: } \\
13\end{array}$ & $\begin{array}{c}\text { Low } \\
\text { grade: } \\
18 \% \\
\text { High } \\
\text { grade: } \\
82 \%\end{array}$ & NR & NR & NR & 0 \\
\hline \multirow[t]{2}{*}{$\begin{array}{l}\text { Müller et al } \\
\text { [30] }\end{array}$} & 2007 & $\begin{array}{l}\text { Single-centre } \\
\text { retrospective }\end{array}$ & 3 & Open & 19 & $\begin{array}{c}\text { Transperitoneal: } \\
16 \% \\
\text { Retroperitoneal: } \\
84 \%\end{array}$ & $\begin{array}{c}\text { Open } \\
\text { extravesical: } 74 \% \\
\text { Endoscopic: } 26 \%\end{array}$ & $\begin{array}{l}\text { Mean: } \\
24\end{array}$ & $\begin{array}{l}\text { Low } \\
\text { grade: } \\
26.3 \% \\
\text { High } \\
\text { grade: } \\
52.6 \%\end{array}$ & 0 & 0 & 5.3 & NR \\
\hline & & & & Laparoscopic & 19 & $\begin{array}{c}\text { Transperitoneal: } \\
10 \% \\
\text { Retroperitoneal: } \\
90 \%\end{array}$ & $\begin{array}{c}\text { Open } \\
\text { extravesical: } 37 \% \\
\text { Endoscopic: } 53 \% \\
\text { Laparoscopic } \\
\text { extravesical: } 10 \%\end{array}$ & $\begin{array}{l}\text { Mean: } \\
17\end{array}$ & $\begin{array}{l}\text { Low } \\
\text { grade: } \\
47.4 \% \\
\text { High } \\
\text { grade: } \\
42.1 \%\end{array}$ & 0 & 0 & 10.5 & NR \\
\hline
\end{tabular}


Table 2 - Oncological outcomes

\begin{tabular}{|c|c|c|c|c|c|c|c|c|c|c|c|c|c|c|}
\hline \multirow[t]{2}{*}{ Study } & \multirow[t]{2}{*}{$\begin{array}{l}\text { Surgical } \\
\text { approaches }\end{array}$} & \multirow{2}{*}{$\begin{array}{l}\text { Number } \\
\text { of } \\
\text { patients }\end{array}$} & \multirow[t]{2}{*}{$\begin{array}{l}\text { Port-site } \\
\text { metastasis }\end{array}$} & \multirow{2}{*}{$\begin{array}{l}5 \text {-yr } \\
\text { cancer- } \\
\text { specific } \\
\text { survival }\end{array}$} & \multirow[t]{2}{*}{$p$ value } & \multirow{2}{*}{$\begin{array}{l}5 \text {-yr } \\
\text { overall } \\
\text { survival }\end{array}$} & \multirow[t]{2}{*}{$\begin{array}{c}p \\
\text { value }\end{array}$} & \multirow{2}{*}{$\begin{array}{l}\text { 5-yr } \\
\text { recurrence- } \\
\text { free } \\
\text { survival }\end{array}$} & \multirow[t]{2}{*}{$p$ value } & \multirow{2}{*}{$\begin{array}{l}\text { 5-yr } \\
\text { bladder } \\
\text { recurrence- } \\
\text { free } \\
\text { survival } \\
\end{array}$} & \multirow[t]{2}{*}{$\begin{array}{c}p \\
\text { value }\end{array}$} & \multicolumn{3}{|c|}{$\begin{array}{l}\text { Multivariable Cox regression } \\
\text { analysis }\end{array}$} \\
\hline & & & & & & & & & & & & $\begin{array}{c}\text { HR } \\
\text { (LNU vs } \\
\text { ONU) }\end{array}$ & $95 \% \mathrm{Cl}$ & $p$ value \\
\hline \multicolumn{15}{|c|}{ Combined laparoscopic RNU vs open RNU } \\
\hline \multirow[t]{2}{*}{ Kawauchi et al [16] } & Open & 34 & NA & NR & & NR & & NR & & $49 \mathrm{mo}:$ & & & & \\
\hline & $\begin{array}{l}\text { Laparoscopic } \\
\text { hand assisted }\end{array}$ & 34 & 0 & NR & NR & NR & NR & NR & NR & $\begin{array}{l}38.2 \% \\
49 \mathrm{mo}: \\
8.8 \%\end{array}$ & NR & NR & NR & NR \\
\hline Okegawa et al [20] & $\begin{array}{l}\text { Open } \\
\text { Laparoscopic }\end{array}$ & $\begin{array}{l}24 \\
25\end{array}$ & $\begin{array}{l}\text { NA } \\
0\end{array}$ & $\begin{array}{l}\text { NR } \\
\text { NR }\end{array}$ & 0.86 & $\begin{array}{l}\text { NR } \\
\text { NR }\end{array}$ & NR & $\begin{array}{l}\text { NR } \\
\text { NR }\end{array}$ & 0.76 & $\begin{array}{l}29 \mathrm{mo}: 17 \% \\
24 \mathrm{mo}: 20 \%\end{array}$ & NS & NR & NR & NR \\
\hline \multirow[t]{2}{*}{ Sato et al [21] } & Open & 23 & NA & $2 \mathrm{yr}:$ & & NR & & $\mathrm{NR}$ & & NR & & & & \\
\hline & $\begin{array}{l}\text { Laparoscopic } \\
\text { hand assisted }\end{array}$ & 36 & 0 & $\begin{array}{l}91 \% \\
2 \mathrm{yr}: \\
94 \%\end{array}$ & 0.83 & NR & NR & NR & NR & NR & 0.67 & NR & NR & NR \\
\hline \multirow[t]{2}{*}{ Rouprêt et al [24] } & Open & 26 & NA & $61.5 \%$ & 0.31 & $19.2 \%$ & 1 & $51.2 \%$ & 0.59 & $\begin{array}{l}78 \mathrm{mo}: \\
15.4 \%\end{array}$ & NS & NR & $\mathrm{NR}$ & NR \\
\hline & Laparoscopic & 20 & NR & $90 \%$ & & $5 \%$ & & $71.6 \%$ & & $69 \mathrm{mo}: 10 \%$ & & & & \\
\hline Lee et al [25] & Laparoscopic & 22 & NA & NR & NR & $\begin{array}{l}30 \mathrm{mo}: \\
82.7 \% \\
14 \mathrm{mo}: \\
90.9 \%\end{array}$ & NR & NR & NR & $\begin{array}{l}30 \mathrm{mo}: \\
17.2 \% \\
14 \mathrm{mo}: \\
4.5 \%\end{array}$ & NR & NR & NR & NR \\
\hline \multirow[t]{2}{*}{ Chung et al [26] } & Open & 41 & NA & $86.1 \%$ & & $72.2 \%$ & & NR & & NR & & & & \\
\hline & $\begin{array}{l}\text { Laparoscopic } \\
\text { hand assisted }\end{array}$ & 25 & NR & $89.7 \%$ & 0.71 & $82.1 \%$ & 0.51 & NR & 0.57 & NR & 0.33 & NR & $\mathrm{NR}$ & NR \\
\hline \multirow[t]{2}{*}{ Kong et al [27] } & Open & 22 & NA & $1 \mathrm{yr}:$ & & $1 \mathrm{yr}:$ & & NR & & $31 \mathrm{mo}:$ & & & & \\
\hline & Laparoscopic & 23 & NR & $\begin{array}{l}100 \% \\
1 \mathrm{yr}: \\
100 \%\end{array}$ & NR & $\begin{array}{l}100 \% \\
1 \mathrm{yr}: \\
100 \%\end{array}$ & NR & NR & NR & $\begin{array}{l}13.6 \% \\
17 \mathrm{mo}: 13 \%\end{array}$ & NR & NR & NR & NR \\
\hline \multirow{3}{*}{$\begin{array}{l}\text { Koda et al } \\
\text { [28] } \\
\text { Nakashima et al } \\
\text { [29] }\end{array}$} & $\begin{array}{l}\text { Open } \\
\text { Laparoscopic }\end{array}$ & $\begin{array}{l}27 \\
79\end{array}$ & $\begin{array}{l}\text { NA } \\
\text { NR }\end{array}$ & $\begin{array}{l}\mathrm{NR} \\
\mathrm{NR}\end{array}$ & NR & $\begin{array}{l}\text { NR } \\
\text { NR }\end{array}$ & $\mathrm{NR}$ & $\begin{array}{l}\text { NR } \\
\text { NR }\end{array}$ & NR & $\begin{array}{l}2 \text { yr: } 60 \% \\
2 \text { yr: } 55 \%\end{array}$ & 0.51 & NR & NR & NR \\
\hline & Open & 37 & NA & $\begin{array}{l}2 \mathrm{yr}: \\
914 \%\end{array}$ & & NR & & NR & & 2 yr: $51.3 \%$ & & & & \\
\hline & $\begin{array}{l}\text { Laparoscopic } \\
\text { hand assisted }\end{array}$ & 35 & NR & $\begin{array}{l}91.4 \% \\
2 \text { yr: } \\
89.3 \%\end{array}$ & NS & NR & NR & NR & NR & 2 yr: $51.8 \%$ & NS & NR & NR & NR \\
\hline \multirow{2}{*}{$\begin{array}{l}\text { Chung et al. } \\
\text { [26] }\end{array}$} & Open & 36 & NA & $86.1 \%$ & & $72.2 \%$ & & NR & & NR & & & & \\
\hline & $\begin{array}{l}\text { Laparoscopic } \\
\text { hand assisted }\end{array}$ & 39 & NR & $89.7 \%$ & 0.71 & $82.1 \%$ & 0.51 & NR & 0.57 & $\mathrm{NR}$ & 0.33 & NR & NR & NR \\
\hline \multirow{2}{*}{$\begin{array}{l}\text { Taweemonkongsap } \\
\text { et al [31] }\end{array}$} & Open & 29 & NA & $2 \mathrm{yr}:$ & & $83.3 \%$ & & NR & & $26 \mathrm{mo:} 45 \%$ & & & RFS: & \\
\hline & Laparoscopic & 31 & 0 & $\begin{array}{l}92.5 \% \\
2 \text { yr: } \\
86.3 \%\end{array}$ & 0.82 & $86.3 \%$ & 0.86 & NR & 0.27 & $28 \mathrm{mo}: 29 \%$ & 0.28 & RFS: 1.5 & $\begin{array}{l}0.67- \\
3.35\end{array}$ & $\begin{array}{l}\text { RFS: } \\
0.32\end{array}$ \\
\hline Waldert et al [33] & Open & 59 & NA & $80 \%$ & 0.62 & NR & $\mathrm{NR}$ & $76 \%$ & 0.82 & $41 \mathrm{mo}:$ & $\mathrm{NR}$ & $\mathrm{NR}$ & $N R$ & $\mathrm{NR}$ \\
\hline
\end{tabular}




\begin{tabular}{|c|c|c|c|c|c|c|c|c|c|c|c|c|c|c|}
\hline & Laparoscopic & 43 & 0 & $85 \%$ & & NR & & $79 \%$ & & $\begin{array}{l}27.1 \% \\
41 \mathrm{mo}: \\
25.6 \%\end{array}$ & & & & \\
\hline \multirow[t]{2}{*}{ Chung et al [35] } & Open & 31 & NA & $82.6 \%$ & \multirow[b]{2}{*}{0.17} & $67.7 \%$ & \multirow[b]{2}{*}{0.57} & NR & \multirow[b]{2}{*}{0.19} & 115 mo: & \multirow[b]{2}{*}{ NR } & \multirow[b]{2}{*}{ NR } & \multirow[b]{2}{*}{ NR } & \multirow[b]{2}{*}{ NR } \\
\hline & $\begin{array}{l}\text { Laparoscopic } \\
\text { hand assisted }\end{array}$ & 21 & 0 & $94.7 \%$ & & $79.6 \%$ & & NR & & $\begin{array}{l}32.3 \% \\
72 \mathrm{mo}: 19 \%\end{array}$ & & & & \\
\hline \multirow[t]{2}{*}{ Ariane et al [41] } & Open & 459 & NA & $78 \%$ & \multirow[b]{2}{*}{$\begin{array}{c}0.06 \\
\text { (for } \\
\text { pT3/pT4: } \\
0.05 \text { ) }\end{array}$} & NR & \multirow[b]{2}{*}{$\mathrm{NR}$} & $50.7 \%$ & & NR & \multirow[b]{2}{*}{ NR } & \multirow[b]{2}{*}{$\begin{array}{l}\text { CSS: } 0.51 \\
\text { RFS: } 1.27\end{array}$} & CSS: & \\
\hline & Laparoscopic & 150 & $3(2 \%)$ & $90.7 \%$ & & NR & & $52.2 \%$ & $\begin{array}{c}0.7 \\
\text { (for } \\
\text { pT3/4: } \\
0.9 \text { ) }\end{array}$ & NR & & & $\begin{array}{c}0.25- \\
1.01 \\
\text { RFS: } \\
0.88- \\
1.83\end{array}$ & $\begin{array}{l}\text { CSS: } \\
0.06 \\
\text { RFS: } \\
0.18\end{array}$ \\
\hline \multirow{3}{*}{$\begin{array}{l}\text { Lotrecchiano et al } \\
\text { [42] } \\
\text { Kim et al [50] }\end{array}$} & $\begin{array}{l}\text { Open } \\
\text { Laparoscopic }\end{array}$ & $\begin{array}{l}32 \\
36\end{array}$ & $\begin{array}{l}\text { NA } \\
1(2.8 \%)\end{array}$ & $\begin{array}{l}\text { NR } \\
\text { NR }\end{array}$ & \multirow[t]{2}{*}{ NR } & $\begin{array}{l}\text { NR } \\
\text { NR }\end{array}$ & \multirow[t]{2}{*}{ NR } & $\begin{array}{l}\text { NR } \\
\text { NR }\end{array}$ & \multirow[t]{2}{*}{$N R$} & $\begin{array}{l}\mathrm{NR} \\
\mathrm{NR}\end{array}$ & \multirow[t]{2}{*}{$N R$} & \multirow[t]{2}{*}{ NR } & NR & \multirow[t]{2}{*}{ NR } \\
\hline & Open & 271 & NA & $80.2 \%$ & & $75.2 \%$ & & NR & & 3 yr: $59.9 \%$ & & & $\begin{array}{l}\text { CSS: } \\
1.23-\end{array}$ & \\
\hline & Laparoscopic & 100 & NR & $66.1 \%$ & $0.03^{*}$ & $59.1 \%$ & $0.01^{*}$ & NR & NR & 3 yr: $61.7 \%$ & 0.27 & $\begin{array}{l}\text { CSS: } 2.08 \\
\text { OS: } 2.21\end{array}$ & $\begin{array}{c}3.52 \\
\text { OS: } \\
1.38- \\
3.53\end{array}$ & $\begin{array}{l}0.006 \\
\text { OS: } \\
0.001\end{array}$ \\
\hline \multicolumn{15}{|c|}{ Pure laparoscopic RNU vs open RNU } \\
\hline \multirow[t]{2}{*}{ Simone et al [9] } & Open & 40 & NA & $89.9 \%$ & \multirow{2}{*}{$\begin{array}{c}0.2 \\
\text { (for pT3: } \\
0.04^{\star} ; \text { for } \\
\text { HG: } \\
0.01^{\star} \text { ) }\end{array}$} & NR & \multirow[b]{2}{*}{ NR } & $77.4 \%$ & \multirow{2}{*}{$\begin{array}{c}0.12 \\
\text { (for } \\
\text { pT3: } \\
0.004^{*} \text {; } \\
\text { for HG: } \\
0.01^{*} \text { ) }\end{array}$} & NR & \multirow[b]{2}{*}{0.86} & \multirow[b]{2}{*}{ NR } & \multirow[b]{2}{*}{ NR } & \\
\hline & Laparoscopic & 40 & $1(2.5 \%)$ & $79.8 \%$ & & NR & & $72.5 \%$ & & NR & & & & NR \\
\hline Greco et al [36] & $\begin{array}{l}\text { Open } \\
\text { Laparoscopic }\end{array}$ & $\begin{array}{l}70 \\
70\end{array}$ & $\begin{array}{l}\text { NA } \\
0\end{array}$ & $\begin{array}{l}\mathrm{NR} \\
\mathrm{NR}\end{array}$ & \multirow[t]{2}{*}{ NR } & $\begin{array}{l}\mathrm{NR} \\
\mathrm{NR}\end{array}$ & \multirow[t]{2}{*}{ NR } & $\begin{array}{l}73 \% \\
75 \%\end{array}$ & $0.04^{*}$ & $\begin{array}{l}\mathrm{NR} \\
\mathrm{NR}\end{array}$ & NR & NR & NR & NR \\
\hline Fang et al [47] & Open & 36 & NA & NR & & NR & & $31 \mathrm{mo:}$ & & NR & & & & \\
\hline & Laparoscopic & 29 & NR & NR & NR & NR & NR & $\begin{array}{l}58.3 \% \\
22 \mathrm{mo}: \\
62.1 \%\end{array}$ & NR & NR & NR & NR & NR & NR \\
\hline Unspecified/het & ogeneous la & $\operatorname{aros}$ & vs open & $\mathrm{VU}$ & & & & & & & & & & \\
\hline Kim et al [17] & Open & 17 & NA & NR & NR & NR & NR & NR & NR & $\begin{array}{l}26 \mathrm{mo}: \\
11.8 \%\end{array}$ & NR & NR & NR & NR \\
\hline & Laparoscopic & 10 & NR & NR & & NR & & NR & & $19 \mathrm{mo}: 20 \%$ & & & & \\
\hline Tsujihata et al [18] & Open & 24 & NA & NR & & NR & & NR & & $22 \mathrm{mo}:$ & & & & \\
\hline & Laparoscopic & 25 & NR & NR & $\mathrm{NR}$ & NR & $\mathrm{NR}$ & NR & 0.82 & $\begin{array}{l}33.3 \% \\
22 \mathrm{mo}: 28 \%\end{array}$ & NR & NR & NR & NR \\
\hline Hattori et al [19] & $\begin{array}{l}\text { Open } \\
\text { Laparoscopic }\end{array}$ & $\begin{array}{l}60 \\
89\end{array}$ & $\begin{array}{l}\text { NA } \\
0\end{array}$ & $\begin{array}{l}78 \% \\
81 \%\end{array}$ & 0.89 & $\begin{array}{l}\text { NR } \\
\text { NR }\end{array}$ & NR & $\begin{array}{l}71 \% \\
71 \%\end{array}$ & 0.91 & $\begin{array}{l}56 \% \\
51 \%\end{array}$ & 0.38 & NR & NR & NR \\
\hline Raman et al [5] & Open & 38 & NA & NR & NR & NR & NR & NR & NR & $51 \mathrm{mo}:$ & NR & NR & NR & NR \\
\hline
\end{tabular}




\begin{tabular}{|c|c|c|c|c|c|c|c|c|c|c|c|c|c|c|}
\hline & $\begin{array}{l}\text { Laparoscopic } \\
\text { hand assisted }\end{array}$ & 52 & 0 & NR & & NR & & NR & & $\begin{array}{l}34.6 \% \\
32 \mathrm{mo}: \\
28.9 \%\end{array}$ & & & & \\
\hline \multirow[t]{2}{*}{ Hsueh et al [22] } & Open & 77 & NA & NR & & NR & & 2 yr: $73 \%$ & & $54 \mathrm{mo:}$ & & & & \\
\hline & $\begin{array}{l}\text { Laparoscopic } \\
\text { hand assisted }\end{array}$ & 66 & NR & NR & 0.98 & NR & 0.74 & 2 yr: $77 \%$ & 0.95 & $\begin{array}{l}24.7 \% \\
38 \mathrm{mo}: 20 \%\end{array}$ & NR & NR & NR & NR \\
\hline \multirow[t]{2}{*}{ Manabe et al [23] } & Open & 166 & NA & $2 \mathrm{yr}:$ & & $2 \mathrm{yr}:$ & & NR & & $28 \mathrm{mo}: 38 \%$ & & & & \\
\hline & Laparoscopic & 58 & $1(1.7 \%)$ & $\begin{array}{l}87 \% \\
2 \text { yr: } \\
85.2 \%\end{array}$ & 0.89 & $\begin{array}{l}83.6 \% \\
2 \text { yr: } \\
83.7 \%\end{array}$ & 0.53 & NR & NR & $\begin{array}{l}14 \mathrm{mo}: \\
32.8 \%\end{array}$ & 0.48 & NR & NR & NR \\
\hline \multirow[t]{2}{*}{ Hemal et al [32] } & Open & 27 & NA & $92.6 \%$ & & $85.2 \%$ & & $88.8 \%$ & & $\begin{array}{l}57 \mathrm{mo}: \\
11.1 \%\end{array}$ & & & & \\
\hline & Laparoscopic & 21 & 0 & $95.2 \%$ & 1 & $85.7 \%$ & 1 & $90.5 \%$ & 1 & $\begin{array}{l}54 \mathrm{mo}: \\
9.5 \%\end{array}$ & 1 & $\mathrm{NR}$ & $\mathrm{NR}$ & $\mathrm{NR}$ \\
\hline Capitanio et al [34] & $\begin{array}{l}\text { Open } \\
\text { Laparoscopic }\end{array}$ & $\begin{array}{l}979 \\
270\end{array}$ & $\begin{array}{l}\text { NA } \\
\text { NR }\end{array}$ & $\begin{array}{l}73.1 \% \\
85.8 \%\end{array}$ & $0.008^{*}$ & $\begin{array}{l}\text { NR } \\
\text { NR }\end{array}$ & NR & $\begin{array}{l}76.2 \% \\
86.8 \%\end{array}$ & $<0.001^{*}$ & $\begin{array}{l}\text { NR } \\
\text { NR }\end{array}$ & NR & $\begin{array}{l}\text { CSS: } 1.54 \\
\text { RFS: } 1.44\end{array}$ & $\begin{array}{c}\text { CSS: } \\
\text { NR } \\
\text { RFS: } \\
\text { NR }\end{array}$ & $\begin{array}{c}\text { CSS: } \\
0.1 \\
\text { RFS: } \\
0.1\end{array}$ \\
\hline Aguilera et al [37] & $\begin{array}{l}\text { Open } \\
\text { Laparoscopic }\end{array}$ & $\begin{array}{l}31 \\
21\end{array}$ & $\begin{array}{l}\text { NA } \\
0\end{array}$ & $\begin{array}{l}\text { NR } \\
\text { NR }\end{array}$ & NR & $\begin{array}{l}\text { NR } \\
\text { NR }\end{array}$ & NS & $\begin{array}{l}\text { NR } \\
\text { NR }\end{array}$ & NR & $\begin{array}{l}\mathrm{NR} \\
\mathrm{NR}\end{array}$ & NR & NR & NR & NR \\
\hline \multirow[t]{2}{*}{ Favaretto et al [38] } & Open & 109 & NA & $\begin{array}{l}2 \mathrm{yr}: \\
86 \%\end{array}$ & & NR & & 2 yr: $38 \%$ & & $\begin{array}{l}23 \mathrm{mo}: \\
46.8 \%\end{array}$ & & & $\begin{array}{l}\text { RFS: } \\
0.57-\end{array}$ & RFS: \\
\hline & Laparoscopic & 53 & NR & $\begin{array}{l}2 \mathrm{yr}: \\
82 \%\end{array}$ & 0.9 & NR & NR & 2 yr: $42 \%$ & 0.9 & $\begin{array}{l}23 \mathrm{mo}: \\
28.3 \%\end{array}$ & NR & $\begin{array}{c}\text { RFS: } 0.88 \\
\text { BRFS: } 0.78\end{array}$ & $\begin{array}{c}1.38 \\
\text { BRFS: } \\
0.46- \\
1.34\end{array}$ & $\begin{array}{c}0.6 \\
\text { BRFS: } \\
0.4\end{array}$ \\
\hline Stewart et al [39] & $\begin{array}{l}\text { Open } \\
\text { Laparoscopic }\end{array}$ & $\begin{array}{l}39 \\
23\end{array}$ & $\begin{array}{l}\text { NA } \\
\text { NR }\end{array}$ & $\begin{array}{l}80 \% \\
71 \%\end{array}$ & 0.43 & $\begin{array}{l}64 \% \\
61 \%\end{array}$ & 0.51 & $\begin{array}{l}\text { NR } \\
\text { NR }\end{array}$ & NR & $\begin{array}{l}58 \% \\
55 \%\end{array}$ & 0.9 & NR & NR & NR \\
\hline \multirow[t]{2}{*}{ Walton et al [40] } & $\begin{array}{l}\text { Open } \\
\text { Laparoscopic }\end{array}$ & $\begin{array}{l}703 \\
70\end{array}$ & $\begin{array}{l}\text { NA } \\
\text { NR }\end{array}$ & $\begin{array}{l}75.4 \% \\
75.2 \%\end{array}$ & & $\begin{array}{l}\text { NR } \\
\text { NR }\end{array}$ & & $\begin{array}{l}73.7 \% \\
63.4 \%\end{array}$ & & $\begin{array}{l}\mathrm{NR} \\
\mathrm{NR}\end{array}$ & & & $\begin{array}{l}\text { CSS: } \\
0.4-\end{array}$ & css: \\
\hline & & & & & 0.9 & & NR & & 0.12 & & NR & $\begin{array}{l}\text { CSS: } 0.96 \\
\text { RFS: } 1.48\end{array}$ & $\begin{array}{c}2.06 \\
\text { RFS: } \\
0.89- \\
2.44\end{array}$ & $\begin{array}{l}0.91 \\
\text { RFS: } \\
0.13\end{array}$ \\
\hline Hamada et al [43] & $\begin{array}{l}\text { Open } \\
\text { Laparoscopic }\end{array}$ & $\begin{array}{l}50 \\
55\end{array}$ & $\begin{array}{l}\text { NA } \\
\text { NR }\end{array}$ & $\begin{array}{l}80 \% \\
77.9 \%\end{array}$ & 0.93 & $\begin{array}{l}\text { NR } \\
\text { NR }\end{array}$ & NR & $\begin{array}{l}68.5 \% \\
71.4 \%\end{array}$ & 0.97 & $\begin{array}{l}56.7 \% \\
57.5 \%\end{array}$ & 0.58 & NR & NR & NR \\
\hline \multirow[t]{2}{*}{ Fairey et al [44] } & $\begin{array}{l}\text { Open } \\
\text { Laparoscopic }\end{array}$ & $\begin{array}{l}403 \\
446\end{array}$ & $\begin{array}{l}\text { NA } \\
\text { NR }\end{array}$ & $\begin{array}{l}73 \% \\
76 \%\end{array}$ & & $\begin{array}{l}67 \% \\
68 \%\end{array}$ & & $\begin{array}{l}44 \% \\
33 \%\end{array}$ & & $\begin{array}{l}\mathrm{NR} \\
\mathrm{NR}\end{array}$ & & & $\begin{array}{l}\text { CSS: } \\
0.6- \\
1.37\end{array}$ & CSS: \\
\hline & & & & & 0.32 & & 0.19 & & 0.06 & & NR & $\begin{array}{c}\text { CSS: } 0.9 \\
\text { OS: } 0.89 \\
\text { RFS: } 1.24\end{array}$ & $\begin{array}{c}\text { OS: } \\
0.6- \\
1.27 \\
\text { RFS: } \\
0.98- \\
1.57\end{array}$ & $\begin{array}{c}\text { O. } 04 \\
\text { OS: } \\
0.52 \\
\text { RFS: } \\
0.08\end{array}$ \\
\hline Izumi et al [45] & Open & 19 & NA & NR & NR & NR & 0.41 & NR & 0.17 & NR & 0.80 & NR & $N R$ & NR \\
\hline
\end{tabular}




\begin{tabular}{|c|c|c|c|c|c|c|c|c|c|c|c|c|c|c|}
\hline \multirow{7}{*}{ Kitamura et al [46] } & Laparoscopic & 46 & NR & NR & & NR & & NR & & NR & & & & \\
\hline & Open & 34 & NA & $74.2 \%$ & & NR & & $57.2 \%$ & & $71.1 \%$ & & & BRFS & \\
\hline & $\begin{array}{l}\text { Laparoscopic: } \\
88 \%\end{array}$ & 74 & NR & HALNU: & & NR & & HALNU: & & HALNU: & & & (HALNU & BRFS \\
\hline & Laparoscopic & & & LNU: & & & & LNU: & & LNU: & & BRFS & ONU): & $\begin{array}{l}\text { (HALNU } \\
\text { vs }\end{array}$ \\
\hline & hand & & & $87.4 \%$ & & & & $69.2 \%$ & & $69.2 \%$ & & (HALNU vs & $2.05-$ & ONU): \\
\hline & assisted: $12 \%$ & & & & 0.56 & & $\mathrm{NR}$ & & $0.04^{*}$ & & $0.002^{*}$ & $\begin{array}{l}\text { ONU) :5.52 } \\
\text { BRFS (LNU }\end{array}$ & $\begin{array}{c}14.6 \\
\text { BRFS }\end{array}$ & $\begin{array}{l}0.001^{*} \\
\text { BRFS }\end{array}$ \\
\hline & & & & & & & & & & & & vs $\mathrm{ONU}): 1.1$ & $\begin{array}{c}\text { (LNU vs } \\
\text { ONU): } \\
0.5- \\
2.57\end{array}$ & $\begin{array}{c}\text { (LNU vs } \\
\text { ONU): } \\
0.82\end{array}$ \\
\hline \multirow[t]{3}{*}{ Zou et al [48] } & Open & 101 & NA & $79.2 \%$ & & NR & & NR & & NR & & & CSS: & \\
\hline & Laparoscopic & 21 & NR & $85.7 \%$ & & NR & & NR & & NR & & & $0.71-$ & CSS: \\
\hline & & & & & 0.56 & & NR & & NR & & NR & $\begin{array}{c}\text { CSS: } 2.38 \\
\text { BRFS: } 0.38\end{array}$ & $\begin{array}{c}7.93 \\
\text { BRFS: } \\
0.08- \\
1.74\end{array}$ & $\begin{array}{c}0.16 \\
\text { BRFS: } \\
0.21\end{array}$ \\
\hline \multirow[t]{2}{*}{ Miyazaki et al [49] } & Open & 527 & NA & $3 \mathrm{yr}:$ & & $3 \mathrm{yr}:$ & & NR & & NR & & & & \\
\hline & Laparoscopic & 222 & NR & $\begin{array}{l}73 \% \\
3 \mathrm{yr}: \\
76 \%\end{array}$ & 0.09 & $\begin{array}{l}69.5 \% \\
3 \text { yr: } \\
72.4 \%\end{array}$ & 0.13 & NR & NR & NR & NR & NR & NR & NR \\
\hline Shan et al [51] & $\begin{array}{l}\text { Open } \\
\text { Laparoscopic }\end{array}$ & $\begin{array}{l}118 \\
100\end{array}$ & $\begin{array}{l}\text { NA } \\
\text { NR }\end{array}$ & $\begin{array}{l}83.8 \% \\
80.8 \%\end{array}$ & 0.69 & $\begin{array}{l}67.1 \% \\
66 \%\end{array}$ & 0.54 & $\begin{array}{l}65.6 \% \\
68.3 \%\end{array}$ & 0.88 & $\begin{array}{l}77.9 \% \\
79.5 \%\end{array}$ & 0.75 & NR & NR & NR \\
\hline
\end{tabular}

\begin{tabular}{|c|c|c|c|c|c|c|c|c|c|c|c|c|c|c|}
\hline \multirow[t]{2}{*}{ Shalhav et al [13] } & Open & 17 & NA & $43 \mathrm{mo}:$ & \multirow[b]{2}{*}{ NR } & \multirow{2}{*}{$\begin{array}{l}43 \mathrm{mo}: \\
91 \% \\
24 \mathrm{mo}: \\
90 \%\end{array}$} & \multirow[b]{2}{*}{ NR } & \multicolumn{2}{|l|}{ NR } & \multicolumn{5}{|l|}{ NR } \\
\hline & Laparoscopic & 25 & 0 & $\begin{array}{l}90 \% \\
24 \mathrm{mo}: \\
90 \%\end{array}$ & & & & NR & NR & NR & NR & NR & NR & NR \\
\hline \multirow[t]{2}{*}{ Gill et al [14] } & Open & 35 & NA & $34 \mathrm{mo}:$ & \multirow[b]{2}{*}{0.59} & $34 \mathrm{mo}:$ & \multirow[b]{2}{*}{0.59} & NR & \multirow[b]{2}{*}{ NR } & $34 \mathrm{mo}: 37 \%$ & \multirow[b]{2}{*}{0.42} & \multirow[b]{2}{*}{ NR } & \multirow[b]{2}{*}{ NR } & \multirow[b]{2}{*}{ NR } \\
\hline & Laparoscopic & 42 & NR & $\begin{array}{l}87 \% \\
11 \mathrm{mo}: \\
97 \%\end{array}$ & & $\begin{array}{l}94 \% \\
11 \mathrm{mo}: \\
97 \%\end{array}$ & & NR & & $11 \mathrm{mo}: 23 \%$ & & & & \\
\hline \multirow[t]{2}{*}{ Stifelman et al [15] } & Open & 11 & NA & NR & \multirow[b]{2}{*}{ NR } & NR & \multirow[b]{2}{*}{ NR } & NR & \multirow[b]{2}{*}{ NR } & $17 \mathrm{mo}:$ & \multirow[b]{2}{*}{ NR } & \multirow[b]{2}{*}{ NR } & \multirow[b]{2}{*}{ NR } & \multirow[b]{2}{*}{ NR } \\
\hline & $\begin{array}{l}\text { Laparoscopic } \\
\text { hand assisted }\end{array}$ & 11 & 0 & NR & & NR & & NR & & $\begin{array}{l}36.4 \% \\
13 \mathrm{mo}: \\
27.3 \%\end{array}$ & & & & \\
\hline Müller et al [30] & $\begin{array}{l}\text { Open } \\
\text { Laparoscopic }\end{array}$ & $\begin{array}{l}19 \\
19\end{array}$ & $\begin{array}{l}\text { NA } \\
0\end{array}$ & $\begin{array}{l}67 \% \\
56.7 \%\end{array}$ & 0.53 & $\begin{array}{l}67 \% \\
56.7 \%\end{array}$ & 0.53 & $\begin{array}{l}\text { NR } \\
\text { NR }\end{array}$ & NR & $\begin{array}{l}2 \text { yr: } 49.5 \% \\
2 \text { yr: } 55.1 \%\end{array}$ & 0.82 & NR & NR & NR \\
\hline
\end{tabular}
recurrence-free survival; RFS = recurrence-free survival; OS = overall survival; CSS = cancer-specific survival; NR = not reported; NA = not applicable; NS = not statistically significant; RNU = radical nephroureterectomy. 
Table 3 - Subgroup analysis in "advanced diseases" (pT3/pT4 and/or high-grade and/or pN+)

\begin{tabular}{|c|c|c|c|c|c|c|c|c|c|c|c|c|c|c|}
\hline \multirow[t]{2}{*}{ Study } & \multirow[t]{2}{*}{$\begin{array}{c}\text { Surgical } \\
\text { approaches }\end{array}$} & \multirow[t]{2}{*}{$\begin{array}{l}\text { Number of } \\
\text { patients }\end{array}$} & \multirow[t]{2}{*}{ Subgroup } & \multirow{2}{*}{$\begin{array}{l}\text { 5-yr cancer- } \\
\text { specific } \\
\text { survival }\end{array}$} & \multirow[t]{2}{*}{$p$ value } & \multirow[t]{2}{*}{$\begin{array}{l}\text { 5-yr overall } \\
\text { survival }\end{array}$} & \multirow[t]{2}{*}{$p$ value } & \multirow{2}{*}{$\begin{array}{c}\text { 5-yr } \\
\text { recurrence- } \\
\text { free survival }\end{array}$} & \multirow[t]{2}{*}{$p$ value } & \multirow{2}{*}{$\begin{array}{l}5 \text {-yr bladder } \\
\text { recurrence- } \\
\text { free survival }\end{array}$} & \multirow[t]{2}{*}{$p$ value } & \multicolumn{3}{|c|}{$\begin{array}{c}\text { Multivariable Cox regression } \\
\text { analysis }\end{array}$} \\
\hline & & & & & & & & & & & & $\begin{array}{c}\text { HR } \\
\text { (LNU vs } \\
\text { ONU) }\end{array}$ & $95 \% \mathrm{Cl}$ & $p$ value \\
\hline \multirow[t]{2}{*}{ Hsueh et al [22] } & Open & 11 & & NR & & NR & & NR & & NR & & & & \\
\hline & $\begin{array}{c}\text { Laparoscopic } \\
\text { hand } \\
\text { assisted }\end{array}$ & 13 & pT3 & NR & 0.48 & NR & 0.12 & NR & NR & NR & NR & NR & NR & NR \\
\hline \multirow[t]{2}{*}{ Hsueh et al [22] } & Open & 34 & & NR & & NR & & NR & & NR & & & & \\
\hline & $\begin{array}{c}\text { Laparoscopic } \\
\text { hand } \\
\text { assisted }\end{array}$ & 38 & G3 & NR & 0.88 & NR & 0.88 & NR & NR & NR & NR & NR & NR & NR \\
\hline \multirow{2}{*}{$\begin{array}{l}\text { Capitanio et al } \\
\text { [34] }\end{array}$} & Open & 344 & NA & NR & & NR & & NR & & NR & & & & \\
\hline & Laparoscopic & 63 & NR & NR & NR & NR & NR & NR & 0.1 & NR & NR & NR & NR & NR \\
\hline \multirow[t]{2}{*}{ Simone et al [9] } & Open & 40 & & NR & & NR & & NR & & NR & & & & \\
\hline & Laparoscopic & 40 & High grade & $N R$ & $0.01^{*}$ & NR & NR & NR & $0.01^{*}$ & NR & NR & NR & NR & NR \\
\hline \multirow[t]{2}{*}{ Simone et al [9] } & Open & 40 & & NR & & NR & & NR & & NR & & & & \\
\hline & Laparoscopic & 40 & pT3 & NR & $0.04^{*}$ & NR & NR & NR & $0.004^{*}$ & NR & NR & NR & NR & NR \\
\hline \multirow[t]{2}{*}{ Chung et al [35] } & Open & 31 & & $82.6 \%$ & & $67.7 \%$ & & NR & & $\begin{array}{c}115 \mathrm{mo}: \\
32.3 \%\end{array}$ & & & & \\
\hline & $\begin{array}{c}\text { Laparoscopic } \\
\text { hand } \\
\text { assisted }\end{array}$ & 21 & pT3N0 & $94.7 \%$ & 0.17 & $79.6 \%$ & 0.57 & NR & 0.19 & $72 \mathrm{mo:} 19 \%$ & NR & NR & NR & NR \\
\hline $\begin{array}{l}\text { Favaretto et al } \\
\text { [38] }\end{array}$ & $\begin{array}{c}\text { Open } \\
\text { Laparoscopic }\end{array}$ & $\begin{array}{l}35 \\
17\end{array}$ & pT3/pT4 & $\begin{array}{l}\text { NR } \\
\text { NR }\end{array}$ & NR & $\begin{array}{l}\text { NR } \\
\text { NR }\end{array}$ & NR & $\begin{array}{l}\text { NR } \\
\text { NR }\end{array}$ & $>0.05$ & $\begin{array}{l}\text { NR } \\
\text { NR }\end{array}$ & NR & NR & NR & NR \\
\hline Walton et al [40] & $\begin{array}{c}\text { Open } \\
\text { Laparoscopic }\end{array}$ & $\begin{array}{c}48 \\
2\end{array}$ & $\mathrm{pN}+$ & $\begin{array}{l}\text { HR: } 0.36 \\
\text { 95\% Cl: } \\
0.04-3.00\end{array}$ & 0.35 & $\begin{array}{l}\text { NR } \\
\text { NR }\end{array}$ & NR & $\begin{array}{c}\text { HR: } 0.21 \\
\text { 95\% Cl: } 0.03- \\
1.81\end{array}$ & 0.16 & $\begin{array}{l}\text { NR } \\
\text { NR }\end{array}$ & NR & NR & NR & $N R$ \\
\hline Walton et al [40] & $\begin{array}{c}\text { Open } \\
\text { Laparoscopic }\end{array}$ & $\begin{array}{l}236 \\
23\end{array}$ & pT3/pT4 & $\begin{array}{c}\text { HR: } 0.77 \\
95 \% \mathrm{Cl}: \\
0.32-1.83\end{array}$ & 0.55 & $\begin{array}{l}\text { NR } \\
\text { NR }\end{array}$ & NR & $\begin{array}{c}\text { HR: } 0.91 \\
95 \% \text { Cl: } 0.44- \\
1.88\end{array}$ & 0.80 & $\begin{array}{l}\text { NR } \\
\text { NR }\end{array}$ & NR & NR & NR & $N R$ \\
\hline Ariane et al [41] & Open & 237 & pT3/pT4 & NR & 0.05 & NR & NR & NR & 0.9 & NR & NR & NR & NR & NR \\
\hline
\end{tabular}




\begin{tabular}{|c|c|c|c|c|c|c|c|c|c|c|c|c|c|c|}
\hline & Laparoscopic & 55 & & NR & & NR & & NR & & NR & & & & \\
\hline Fairey et al [44] & $\begin{array}{l}\text { Open } \\
\text { Laparoscopic }\end{array}$ & $\begin{array}{l}42 \\
18\end{array}$ & $\mathrm{pT}$ and $\mathrm{pN}+$ & $\begin{array}{l}\mathrm{NR} \\
\mathrm{NR}\end{array}$ & NR & $\begin{array}{l}\mathrm{NR} \\
\mathrm{NR}\end{array}$ & NR & $\begin{array}{l}\text { HR: } 1.30 \\
95 \% \text { Cl: } 1.03- \\
1.65\end{array}$ & $0.03^{\star}$ & $\begin{array}{l}\mathrm{NR} \\
\mathrm{NR}\end{array}$ & NR & NR & NR & NR \\
\hline \multirow{2}{*}{$\begin{array}{l}\text { Faireyet al. } \\
\text { [44] }\end{array}$} & Open & 111 & & NR & & NR & & & & NR & & & & \\
\hline & Laparoscopic & 120 & $\begin{array}{l}\text { PT3/pT4 } \\
\text { pN0 }\end{array}$ & NR & NR & NR & NR & $\begin{array}{c}\text { HR: } 0.94 \\
95 \% \text { Cl: } 0.60- \\
1.48\end{array}$ & 0.80 & NR & NR & NR & NR & NR \\
\hline \multirow{2}{*}{$\begin{array}{l}\text { Miyazaki et al } \\
\text { [49] }\end{array}$} & Open & 379 & & NR & & NR & & NR & & NR & & & & \\
\hline & Laparoscopic & 167 & $\begin{array}{c}\mathrm{pT} 3 / \mathrm{pT} 4 \\
\text { and/or pN+ }\end{array}$ & NR & NR & NR & 0.29 & NR & NR & NR & NR & NR & NR & NR \\
\hline \multirow[t]{2}{*}{ Kim et al [50] } & Open & 112 & & $62.7 \%$ & & $68.4 \%$ & & NR & & NR & & & css: & \\
\hline & Laparoscopic & 34 & pT3/pT4 & $26 \%$ & $0.007^{*}$ & $32.7 \%$ & $0.005^{\star}$ & NR & $>0.05$ & NR & $>0.05$ & $\begin{array}{c}\text { CSS: } \\
2.50 \\
\text { OS: } 2.59\end{array}$ & $\begin{array}{c}1.32- \\
4.71 \\
\text { OS: } \\
1.44- \\
4.65\end{array}$ & $\begin{array}{c}\text { CSS: } \\
0.005^{*} \\
\text { OS: } \\
0.001^{*}\end{array}$ \\
\hline
\end{tabular}
nephroureterectomy; $N R=$ not reported; $N A=$ not applicable; $O N U=$ open nephroureterectomy. 